\title{
„Improving the temperature predictions of subsurface thermal models by using high- quality input data. Part 2: A case study from the Danish-German border region"“
}

-Final version (post print)-

Sven Fuchs ${ }^{1,2}$, Niels Balling ${ }^{1}$

${ }^{1}$ Department of Geosciences, Aarhus University, Høegh-Guldbergs Gade 2, 8000 Aarhus C, Denmark.

${ }^{2}$ Now at: Geothermal Energy Systems, GFZ German Research Centre for Geosciences, Telegrafenberg, 14473 Potsdam, Germany, E-mail: fuchs@gfz-potsdam.de

This paper was originally published in:

Geothermics 64, pp 1-14 [Elsevier]

„Improving the temperature predictions of subsurface thermal models by using high-quality input data. Part 2: A case study from the Danish-German border region“"

doi: 10.1016/j.geothermics.2016.04.004

The publisher version is available at:

http://www.sciencedirect.com/science/article/pii/S0375650516300268

Received: 22/12/2015 Accepted: 13/04/2016

My home page is www.hydrogeologist.de where you can find a complete list of my publications.

Contact: $\quad$ sven.fuchs@hydrogeologist.de

Sven Fuchs; May 10, 2016 


\section{Keywords}

3D subsurface thermal modelling, thermal conductivity, radiogenic heat production, terrestrial surface heat flow, temperature maps

\section{Highlights}

- 3D steady-state thermal FE model using Feflow

- Well-log based parameterization approach

- Spatial parameterization of rock thermal conductivity

- New heat-flow data

- North German Basin (Danish-German border area) 


\begin{abstract}
We present a 3D numerical crustal temperature model and analyse the present-day conductive thermal field of the Danish-German border region. The model region covers the northernmost part of the North German Basin, a transition zone between the deep-reaching sedimentary rocks of the Glückstadt Graben (including complex salt structures) and the shallow crystalline basement of the Ringkøbing-Fyn High. The modelling approach is novel as it implements for the first time a comprehensive analysis of well-log data on a regional modelling scale. Those logs were used both to derive the spatial distribution of rock thermal conductivity across the study area, and to calculate heat flow values. New values of terrestrial surface heat flow are reported for eight deep boreholes in the North German Basin ranging from 72 to $84 \mathrm{~mW} / \mathrm{m}^{2}$ with a mean of $80 \pm 5 \mathrm{~mW} / \mathrm{m}^{2}$. The values are computed from continuous temperature logs, carefully corrected BHT values, drill-stem tests and well-log derived rock thermal properties (thermal conductivity, radiogenic heat production) and were included in the setup of the numerical lower boundary conditions. New surface heat flow is up to $20 \mathrm{~mW} / \mathrm{m}^{2}$ higher than low values reported in some previous studies for this region. Heat flow from the mantle is 33 to $40 \mathrm{~mW} / \mathrm{m}^{2}$.

The model temperature predictions are validated against 59 temperature observations from 24 wells. The prediction uncertainties between observed and modelled temperatures at deep borehole sites are small $\left(\mathrm{rms}=3.5^{\circ} \mathrm{C}\right.$, ame $\left.=2.1^{\circ} \mathrm{C}\right)$. Pronounced lateral temperature variations are predicted and found to be caused mainly by complex geological structures, including a large amount of salt structures and marked lateral variations in the thickness of basin sediments. The associated variations in rock thermal conductivity generate significant variations in model heat flow and large variations in temperature gradients.

With regard to the utilization of geothermal energy, the Rhaetian and the Middle Buntsandstein sandstone reservoirs are found with temperatures within the range of $40-80{ }^{\circ} \mathrm{C}$, suitable for low enthalpy heating purposes, in most of the area and locally also with higher temperatures. Temperatures above $120^{\circ} \mathrm{C}$, of interest for the production of electricity, are observed only in the very southeastern part of the study area.
\end{abstract}




\section{Introduction}

Well-constrained thermal models are important for the examination of the subsurface thermal structure and thus the geothermal resources of a region. In border regions like the DanishGerman, located close to the northern margin of the North German Basin (NGB), such models can help to manage geothermal resources and to prevent conflicts of use between the wide range of possible subsurface applications that are technologically or economically affected by the thermal field (e.g. energy resources like geothermal heat or hydrocarbons, geological storage of energy or waste). Information on the geological structure, the configuration of the rock thermal properties and reliable boundary conditions are paramount for the setup of thermal models. While structural information are usually obtained from seismic analysis and borehole data, representative values of rock thermal properties for structural units are often taken over directly from previous modelling studies or from literature. The latter fact generally implements large uncertainties in modelling studies.

In part one of this study (Fuchs and Balling, 2016, this issue), we demonstrated the importance of a high-quality thermal-conductivity (TC) parameterization on the uncertainty of predicted temperature in sedimentary basin models. We have demonstrated that a significant uncertainty reduction can be achieved (1) by using TC values determined from the analysis of lithological bore logs or even better from geophysical well logs instead of implementing literature values, and (2) by considering the spatial TC variability within modelled formations instead of using constant formation values. Considering both aspects resulted in a reduction of uncertainties of modelled temperatures by up to $80 \%$.

In the present paper (part 2), we apply the findings of the first part and assess, in detail, the regional thermal field of the Danish-German border region. We present results from a 3D numerical thermal model which is developed to study the influences of the subsurface geological variability on the temperature field, in particular for the onshore zone between the crystalline basement high of the Ringkфbing-Fyn High (southern Jutland) and the northern part of the Glückstadt Graben (Northernmost Germany) area that is dominated by complex salt structures. New data on present-day surface heat flow (physically: heat-flow density) are presented and implemented in the verification of our 3D conductive thermal model. Modelled temperatures are compared with temperatures measured in boreholes. The final aim of this study is to generate a full 3D subsurface geothermal model and present new temperature maps for geological formations that are proper targets for geothermal exploration (e.g. Rhaetian/Gassum Formation and Middle Buntsandstein) as well as for selected constant depths levels $(1 \mathrm{~km}, 2$ $\mathrm{km}$, etc.). 


\section{Study area and geological setting}

The study area comprises the regions of Southern Jutland (Denmark), Schleswig-Holstein (northernmost Germany) and minor costal parts of the North Sea and of the Baltic Sea. It covers an area of $c .14 .000 \mathrm{~km}^{2}$ (roughly $115 \times 130 \mathrm{~km}$ ) and is located at the northern margin of the NGB, which is a part of the Central European Basin System (CEBS) (Fig. 1).

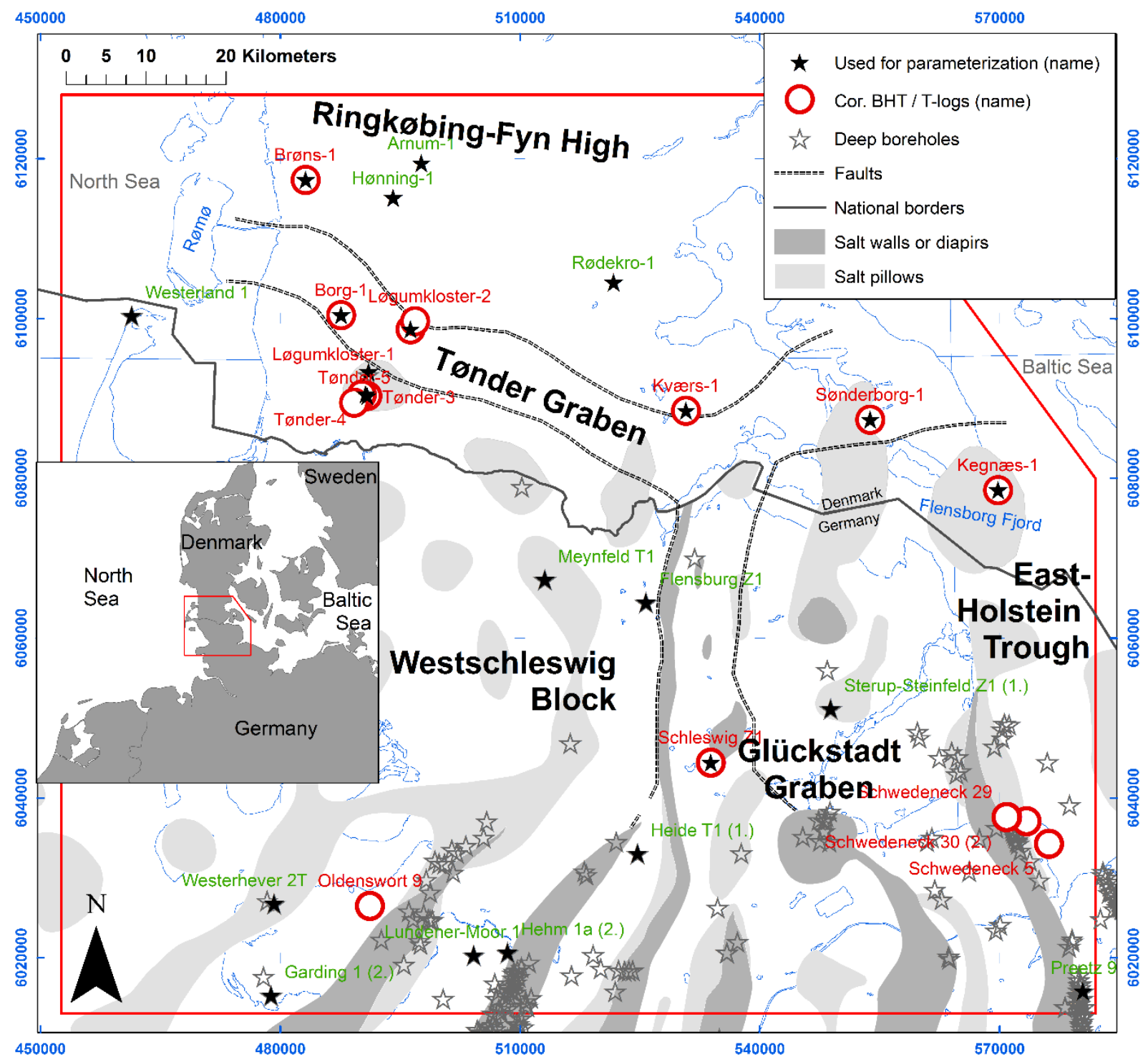

Figure 1. Map of the study area with salt structures (after Kirsch et al., 2015), geological setting and main tectonic units (after Kaufhold et al., 2011) and deep boreholes. Model coordinates are UTM (zone 32N) system using WGS 84 datum.

The NGB usually comprises up to, and locally more than $10 \mathrm{~km}$ sediments of Paleozoic, Mesozoic and Cenozoic age. The largest thickness (>12 km) is located in the central part of the Glückstadt Graben. The regional geology can be subdivided into five main elements: the 
Westschleswig Block in the northwestern part, the Ostholstein-Westmecklenburg-Block in the eastern part, the Glückstadt Graben area in the southeastern part and the NW-SE trending Tønder Graben and Ringkфbing-Fyn High in the North (Rodon and Littke, 2005; Maystrenko et al., 2005a; Michelsen and Clausen, 2002).

The NGB itself was formed as an intra-cratonic basin during the Permo-Carboniferous linked to the Variscan orogeny (rifting and igneous activity) (Ziegler, 1990; Henk, 1999; Benek et al. 1996). The subsidence of the NGB during the Permian (Rotliegend and Zechstein) results in $c$. $1500 \mathrm{~m}$ thick claystones and evaporite rock units (rock salt, anhydrite, gypsum, etc.). Figure 2 shows the main stratigraphic units and the generalized lithology.
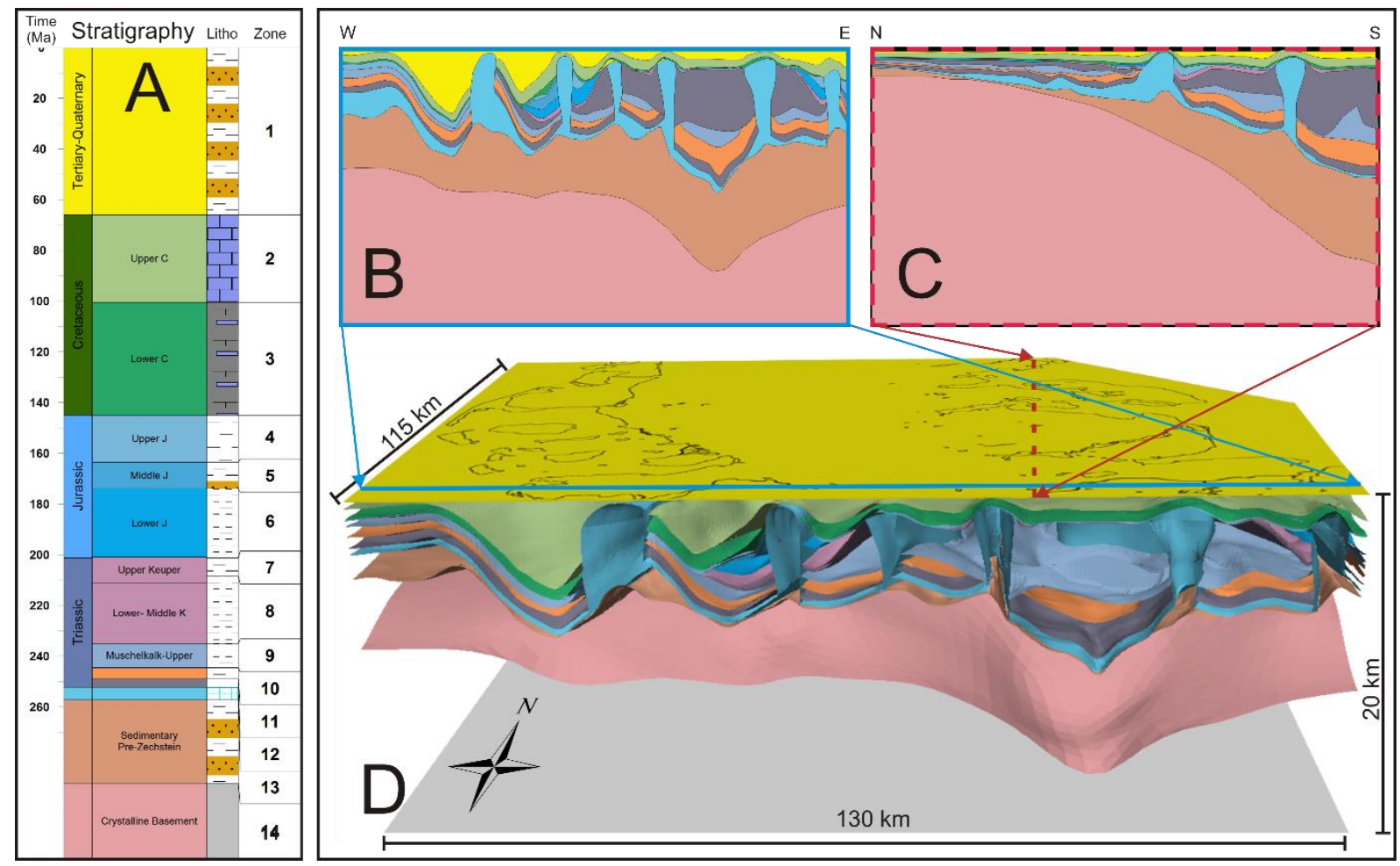

Figure 2. Geology and stratigraphy. A) Stratigraphy, generalized lithology and model units of the study area. B) Simplified geological West-East cross section (blue solid surface line in the 3D sketch), showing salt structures and deep troughs. C) Simplified geological North-South cross section (red dashed surface line in the 3D sketch), showing the shallow crystalline basement of the Ringkøbing-Fyn High in the North and the deep-reaching sediments of the Glückstadt Graben in the South. D) Sketch of the 3D structural model (after Kirsch et al., 2015).

The Glückstadt Graben is one of the deepest post-Permian sub-basins of the CEBS. The sedimentary filling mainly consists of Permian to Cenozoic rocks that overlays a DevonianCarboniferous sequence and a Caledonian consolidated crystalline crust (Bayer et al., 2002). Its Mesozoic evolution is mainly controlled by a Middle-Late Triassic (Keuper) extension (Rodon and Littke, 2005, and references therein). Mobilized salt in the form of pillows, diapirs and roughly N-S striking parallel aligned salt walls, mainly determines the inner structural setup of 
the Glückstadt Graben. The depth of the evaporite Zechstein base is varying between 2 and $10 \mathrm{~km}$. Around salt structures, thickness maxima of Cenozoic and Mesozoic sediments occur in primary and secondary rim synclines. Jurassic sediments, which were often targeted by oil exploration, occur in very deep rim synclines only ( $c f$. Fig. 3). Further details of the evolution of the Glückstadt Graben are summarized in Ziegler (1992), Maystrenko et al. (2005), and Maystrenko et al. (2006).

The Ringkøbing-Fyn High is a NW-SE trending basement ridge which separated the Southern Permian Basin from the Northern Permian Basin during Late Carboniferous to Early Permian times. It consists of a series of shallow fault blocks of Precambrian crystalline rocks (spanning between North Sea and Baltic Sea) and is subdivided by N-S striking graben systems (Brande Graben, Horn Graben), generated in relation to movements along the Sorgenfrei-Tornquist Zone and the Trans European Suture Zone during the Late Carboniferous to Early Permian (Thybo, 1997; Thybo, 2001; Bergerat et al., 2007; Sorgenfrei and Buch, 1964). The EarlyMiddle Jurassic major updoming of the North Sea area (Ziegler, 1990) caused a progressive uplift of the Ringkøbing-Fyn High. Above the Ringkøbing-Fyn High, thin sections of Triassic to Lower Cretaceous sediments are present in the northern part of the study area (Nielsen, 2003). The area between Glückstadt Graben and Ringkøbing-Fyn High is structurally determined by the NW-SE trending Tønder Graben, which forms a narrow tectonic depression extending from Flensborg Fjord to the island of Rømø (Michelsen and Clausen, 2002). This area, similar to the Westschleswig Block, is characterized by weak halogenetic elements, and therefore, can be clearly separated from the Glückstadt Graben. Minor salt pillows are known in several areas, e.g. from the Tønder area (Fig. 1). Further details on the general regional geology can be found in Rodon and Littke (2005) and Kaufhold et al. (2011). Examples of depth and thickness distributions of selected geological units are shown in Fig. 3. Detailed values of thickness and depth of the modelled geological units are summarized in part one of this study (Fuchs and Balling, 2016, this issue). 


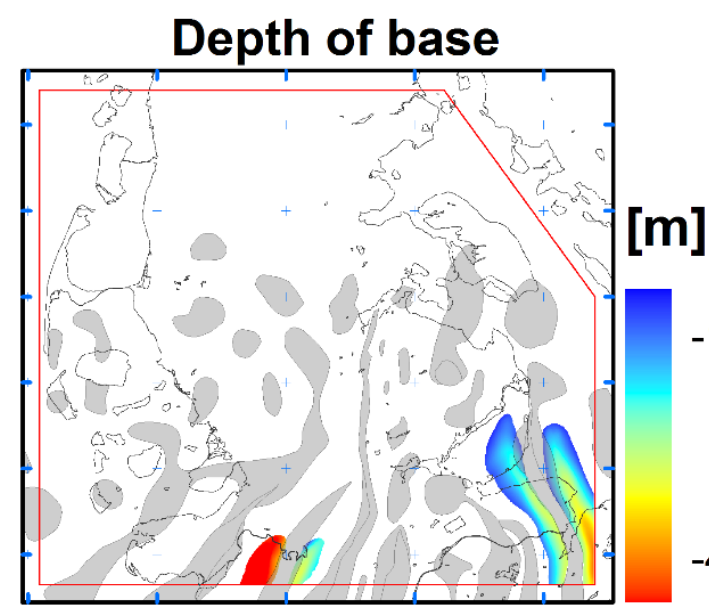

Dogger (Middle Jurassic)

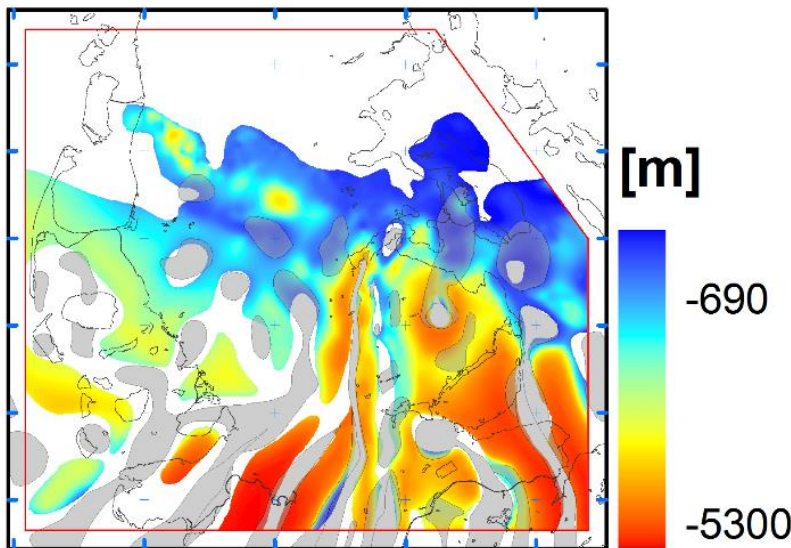

Rhaetian/Gassum Fm. (Upper Keuper)

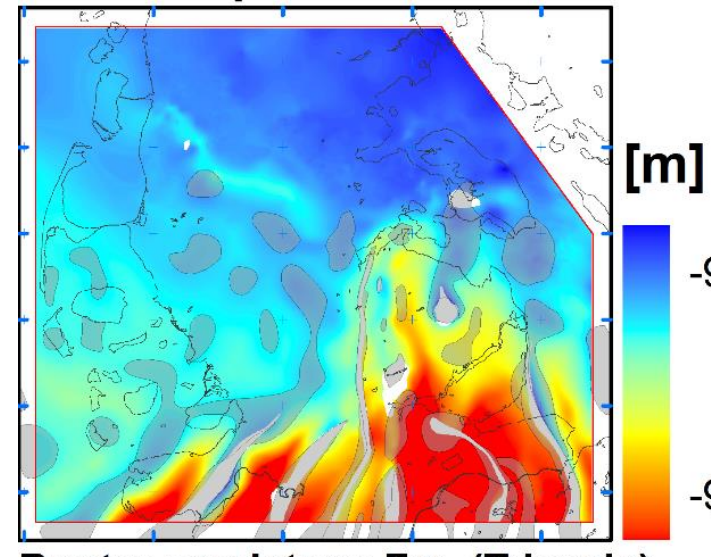

\section{Bunter sandstone Fm. (Triassic)}

$-9310$
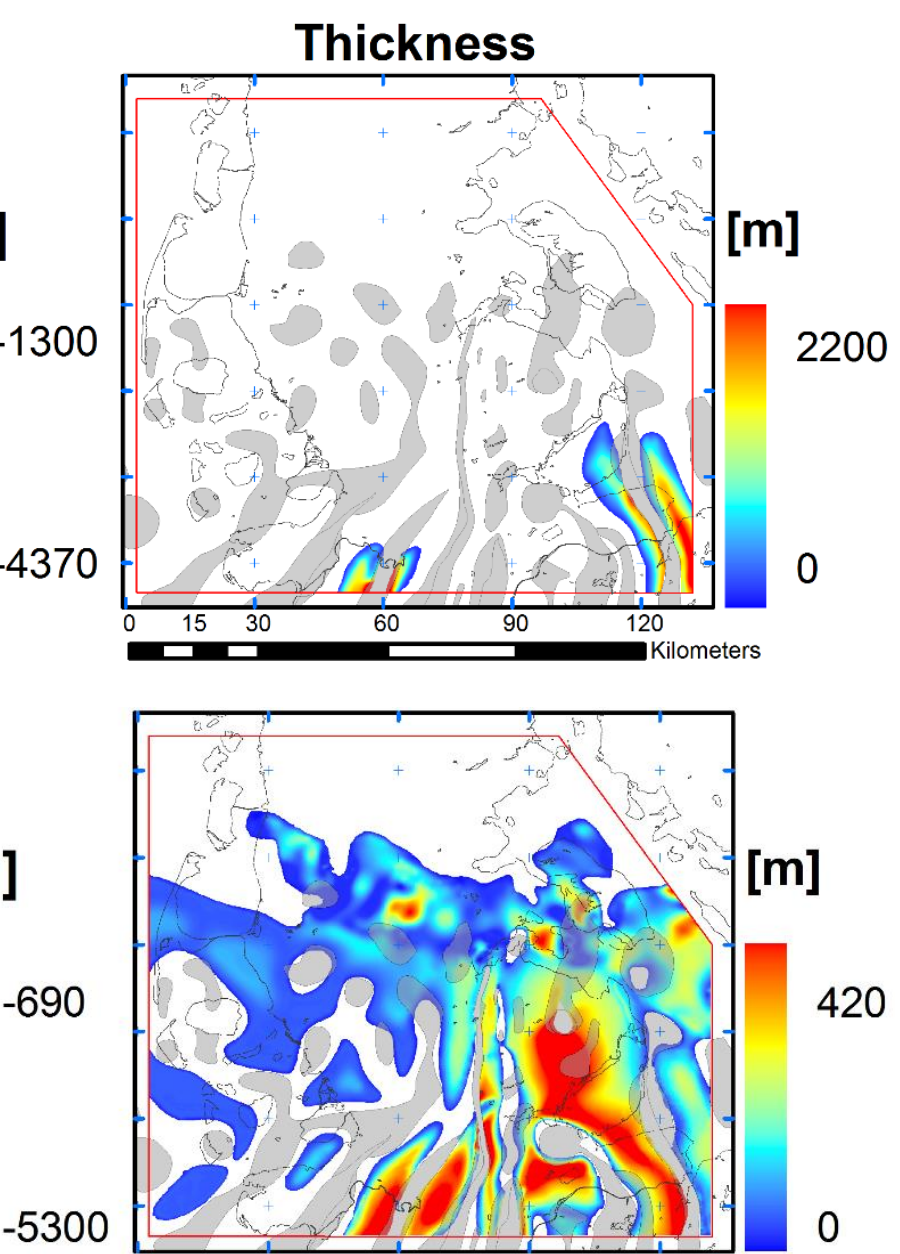

420

2135

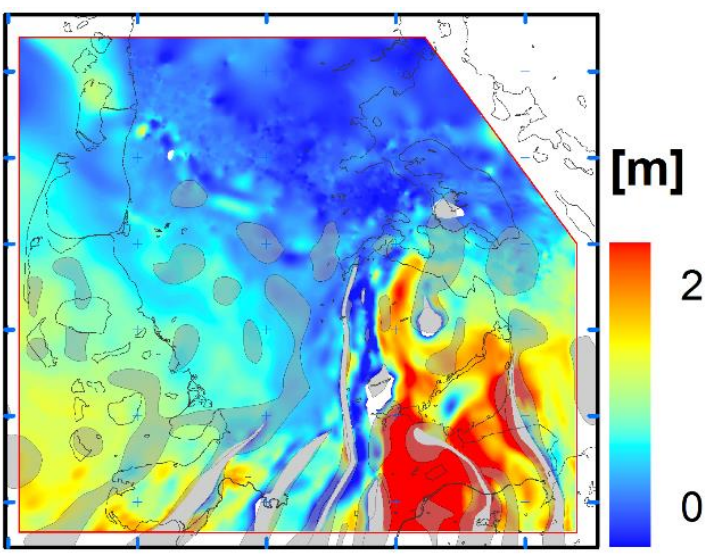

Figure 3. Depths of the base and thickness maps of selected stratigraphic units applied in the 3D geological model (data from Kirsch et al., 2015).

More than 200 deep boreholes have been drilled in the study area and provide valuable insight into the structural and sedimentary evolution of this region. Most of these boreholes were drilled for the exploration of potential geological traps for oil and gas nearby salt structures in the Glückstadt Graben (cf. Fig. 1). Constrained by borehole data and seismic information, a 3D structural model was developed by LLUR (State Agency for Agriculture, Environment and 
Rural Areas Schleswig-Holstein, Germany) and GEUS (Geological Survey of Denmark and Greenland) (Kirsch et al., 2015). Lithological, stratigraphical, petrophysical, and geophysical borehole data of good quality available for more than 70 wells are implemented in this study. Further details to the amount and quality of the used database are reported in part one of this study (Fuchs and Balling, 2016, this issue).

\section{Previous modelling studies}

The NGB was target of several modelling studies over the past two decades. A broad range of scientific issues was examined, with special emphasis on the analysis of the present day thermal structure (e.g. Scheck, 1997; Bayer et al., 1997; Ondrak et al., 1999; Vosteen et al., 2004; Norden et al., 2008; Noack et al., 2010; Norden et al., 2012; P. Balling et al., 2013; Sippel et al., 2013; Scheck-Wenderoth et al., 2014), thermal maturity studies (e.g. Friberg et al., 2000; Rodon and Littke, 2005), type and configuration of basement and lower boundary (e.g. Scheck, 1997; Marotta et al., 2000; Cacace et al., 2010; Noack et al., 2012), reservoir production and lifetime (e.g. Ondrak et al., 1998; Ollinger et al., 2010; Mottaghy et al., 2011; Blöcher et al., 2010), processes of advective and convective heat transfer (e.g. Magri et al., 2005; Magri et al., 2008; Kaiser et al., 2011), and the influence of the meshing procedure (Kaiser et al., 2013). The majority of these studies have documented some common fundamental observations, relevant for modelling the thermal field in the NGB.

(1) Thermal conduction is assumed generally to be the main heat transport mechanism in the North German Basin. The presence and magnitude of thermal advection at basin scale is still a matter of debate.

(2) The interaction of geological structure, thickness distribution and rock thermal properties is paramount for the configuration of the subsurface thermal field.

(3) Where thick layer of mobilized Zechstein salt are accumulated as diapers or walls, salt structures locally act as a conductive 'heat chimney' according to the high TC of rock salt compared with most clastic and carbonate sedimentary rocks. This effect results in higher temperatures in the upper part and above the salt structure and in an increased surface heat flow compared with surrounding areas. In contrast, lower temperatures are observed in the deeper parts and below the salt structure (reduced heat flow).

(4) Where thick accumulations of low-conductive sedimentary rocks are locally present above conductive units, heat is stored below the sealing rocks and higher temperatures are observed. 
This process is generally known as 'thermal blanketing' effect. Where such accumulations are deposited in salt margin synclines, heat refraction effects are also to be expected.

For the present model area (Danish-German border region), some few studies targeted the subsurface thermal field. Previous studies on the subsurface temperatures in the Danish part are known from the regional studies of Balling et al. (1981; 2002) and Balling (1992). For the Glückstadt-Graben area, Rodon and Littke (2005) presented maturity data and put them in the context of burial and temperature history. Based on new vitrinite-reflectance data, they carried out 1D numerical basin models and presented detailed temperature simulation results for six wells. Burial and temperature histories were calibrated by comparing calculated and measured vitrinite-reflectance and temperature data from Haenel (1980). Based on this analysis, a presentday surface heat flow ranging between 45 and $60 \mathrm{~mW} / \mathrm{m}^{2}$ is reported for wells located in our model area.

More recently, P. Balling et al. (2013) developed a 3D lithosphere-scale conductive thermal model for the area of the Glückstadt Graben based on the structural data from Maystrenko et al. (2005a,b, 2006) and Maystrenko and Scheck-Wenderoth (2013). Using a parameter set compiled from several studies, but based mainly on the work of Scheck (1997), Balling and coworkers tested the sensitivity of the assign formation properties by comparing modelled with measured temperatures from six wells. By adjusting the TC and radiogenic heat production (RHP) values of the modelled layers, they found a reasonable fit for five out of six studied wells (Allermöhe, Glückstadt T1, Mittelplate 2, Moelln-Tief 1, Schleswig Z1). For the sixth well (Flensburg Z1), they observed large deviations to measured temperatures and concluded that the steady-state conductive approach is locally invalid. According to the chimney effect, they modelled large thermal anomalies mainly related to the salt structures. Negative anomalies of up to $-35^{\circ} \mathrm{C}$ and positive thermal anomalies of up to $15^{\circ} \mathrm{C}$ underneath and above the salt structure are observed in their thermal model.

\section{Temperature and heat flow}

\subsection{Temperature data}

Over the past decades, various borehole temperature values have been measured in the study area mainly during or after the drilling phases. For the present study, temperature data comprising temperature logs and corrected bottom-hole-temperature values (BHT) are used for the model calibration. This data set includes 36 BHT values from 23 wells (compiled from Poulsen et al., 2013 and Kühne, 2006) and 23 values from a continuous equilibrium temperature 
profile in one well (Balling and Bording, 2013). Each temperature value is attributed with an uncertainty (one standard deviation (SD) for BHT values taken from literature, $1{ }^{\circ} \mathrm{C}$ assumed for temperature logs) and an associated weight factor. This factor is included in the calibration with the Gauss-Levenberg-Marquardt algorithm (GLMA) and reflects the quality of the temperature data. The quality code is based on a modified classification originally introduced by Schulz and Werner (1987), where temperature $\log =1$, BHT cylindrical-source-methodinversion $(\mathrm{CMI})$ corrected $=0.9$, BHT Horner corrected $=0.8$, BHT empirical corrected $=0.4)$. Figure 4 shows the temperature-depth distribution of the applied temperature data.

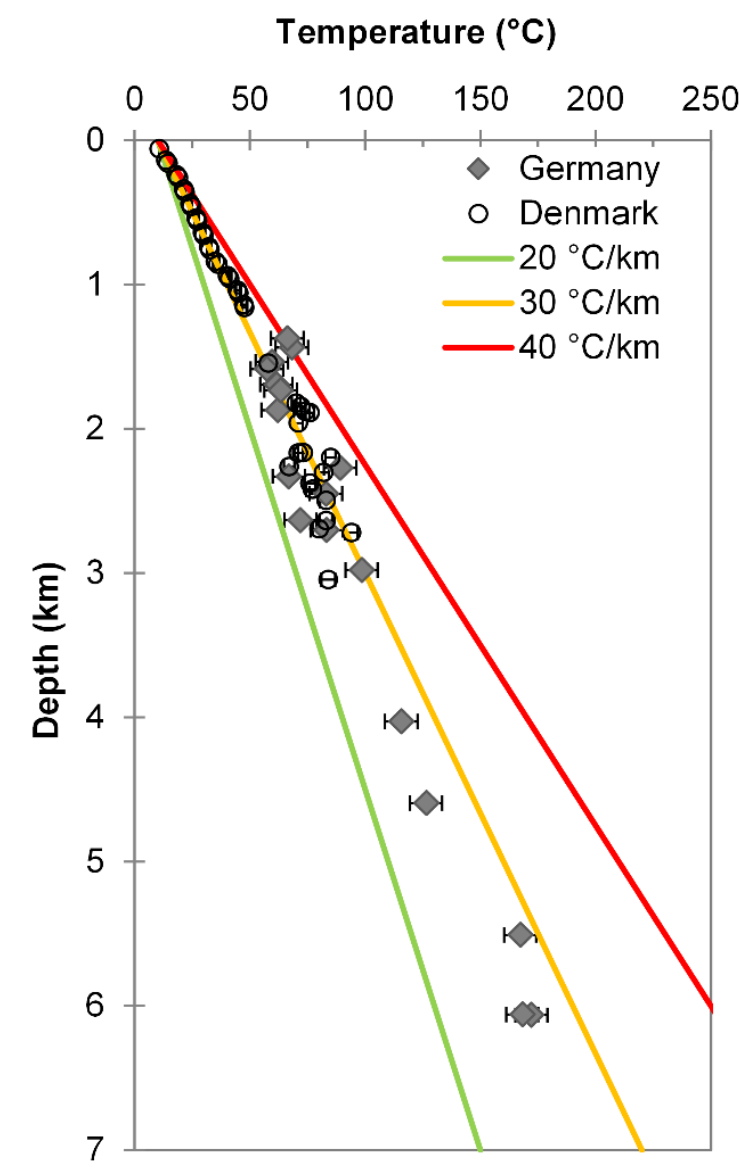

Figure 4. Corrected BHT's and temperature-log values available for wells in the study area.

\subsection{Interval and surface heat flow}

Continuous TC profiles computed from standard well logs ( $c f$. Fuchs et al., 2015) and measured temperature information allow the calculation of interval heat-flow values on different borehole locations and depth intervals. Those values constitute the basis for calculation of the locationsspecific terrestrial surface heat flow and finally for the set-up of the lower thermal boundary condition at $20 \mathrm{~km}$ depth. The interval heat flow $q_{i}$ is computed applying the method of Bullard (Bullard, 1939; Powell et al., 1988), where $\Delta T$ is the temperature difference of a certain depth interval (in ${ }^{\circ} \mathrm{C}$ ), and $R$ is the total thermal resistance of that interval (in $\left(\mathrm{m}^{2} \mathrm{C}\right) / \mathrm{W}$ ): 


$$
q_{i}=\frac{1}{R} \Delta T
$$

The thermal resistance is calculated as

$$
R=\sum_{k}^{z}\left(\frac{\Delta z}{\lambda_{z}}\right)
$$

Heat flow was initially calculated for more than 100 depth intervals at 24 borehole locations. For the final calculations, only heat-flow values that fulfil a number of strict quality criteria are used: a) temperature measurements are observed for depth larger than $1.5 \mathrm{~km}$ (reducing disturbance due to palaeoclimate), b) temperature gradients are calculated for depth intervals of no less than $1.5 \mathrm{~km}$ (reduces the impact of the BHT uncertainties on the temperature-gradient) and c) temperature measurements are located with a minimum distance of $3 \mathrm{~km}$ to salt walls or salt diapirs (avoid major disturbances of the heat-flow field due to heat refraction and chimney effect).

Temperature differences required for eq. 1 are calculated either between subsurface values measured at different depth in a borehole or between specific measurements and an assumed surface-temperature value. This surface temperature is here set to $0{ }^{\circ} \mathrm{C}$ as an estimated longterm characteristic temperature, rather than the present-day mean surface temperature, to consider the palaeoclimatic impact, still effecting the thermal structure of the uppermost 1.5 to $2 \mathrm{~km}$ of the sedimentary succession ( $c f$. Balling, 1979, 1992, Fuchs et al., 2015). For the greater depths, temperatures are assumed to be in approximate equilibrium with a surface temperature of close to $0{ }^{\circ} \mathrm{C}$ considering long time spans (past more than 100.000 years).

The depth interval for the determination of the interval heat flow is $c .2 .7 \mathrm{~km}$ on average (minimum: $1.5 \mathrm{~km}$, maximum: $6 \mathrm{~km}$ ). Finally, 38 interval heat-flow values determined at 16 borehole locations have been considered for further calculations.

The terrestrial surface heat flow $\left(q_{\mathrm{s}}\right)$ and the heat flow at the model bottom $\left(q_{20 \mathrm{~km}}\right)$ are calculated considering the RHP of the over- and underlying rocks. Since the calculated interval values characterize the average heat flow of a certain depth interval, RHP is considered from the middle of that interval to the surface for $q_{\mathrm{s}}$ and to the model base for $q_{20 \mathrm{~km}}$. RHP is calculated using the well-log based procedure described in section 5. Where no borehole-specific RHP is available from well-log analysis, average values calculated for all wells in the study area are implemented ( $c f$. Table 2).

All calculations treated in this section are carried out for selected corrected BHT values and temperature-log data. The mean heat flow is $80.1 \pm 4.9 \mathrm{~mW} / \mathrm{m}^{2}$ for $q_{\mathrm{s}}$ (mean range: $72-84$ $\mathrm{mW} / \mathrm{m}^{2}$ ) and $48.6 \pm 4.5 \mathrm{~mW} / \mathrm{m}^{2}$ for $q_{20 \mathrm{~km}}$ (mean range: $43-51 \mathrm{~mW} / \mathrm{m}^{2}$ ). All heat-flow values are summarized in Table 1 . The $q_{20 \mathrm{~km}}$-mean value is chosen as lower boundary condition in our 
numerical model, whereas the individual $q_{\mathrm{s}}$-values are used as validation data for the numerically modelled surface heat flow ( $c f$. section 6.2).

Temperature data available for heat-flow studies often comprise only uncorrected BHT values or such data may be included. Therefore, for a comparison, we did the same calculations for wells where uncorrected BHT values are available which include eight additional wells not included in Table 1. For these temperature data sets, temperature gradients are expected to be too low due to the cooling effect of the mud circulation during the drilling process. Thus, heat flow calculated from uncorrected BHT is assumed to define a clear lower boundary of the regional surface heat-flow field, while values calculated from corrected BHT, drill-stem tests and equilibrium temperature logs are assumed to give higher and more reliable results. The mean heat flow calculated on basis of the uncorrected BHT values is $67.4 \pm 7.1 \mathrm{~mW} / \mathrm{m}^{2}$ for $q_{\mathrm{s}}$ (range: $50-80 \mathrm{~mW} / \mathrm{m}^{2}$ ) and $35 \pm 7 \mathrm{~mW} / \mathrm{m}^{2}$ for $q_{20 k m}$ (range: $19-49 \mathrm{~mW} / \mathrm{m}^{2}$ ) and is thus, as expected, significantly lower compared with the results of the higher quality data (independent student $t$-test, $p<0.001)$.

Table 1. Heat-flow data for eight sites of deep boreholes in the study area. See text for explanation.

\begin{tabular}{|c|c|c|c|c|c|c|c|c|c|c|c|}
\hline \multirow{2}{*}{ Well } & \multirow{2}{*}{$\begin{array}{l}\text { Long. } \\
\text { E }\end{array}$} & \multirow{2}{*}{$\begin{array}{l}\text { Lat. } \\
\text { N }\end{array}$} & \multicolumn{2}{|c|}{ Intervall } & \multicolumn{2}{|c|}{ Temperature } & \multirow{2}{*}{$\begin{array}{c}\text { Temperatur } \\
\text { e gradient } \\
\Delta T \\
{ }^{\circ} \mathrm{C} / \mathrm{km}\end{array}$} & \multirow{2}{*}{$\begin{array}{c}\begin{array}{c}\text { In-situ thermal } \\
\text { resistance }\end{array} \\
R \\
(m K) / W\end{array}$} & \multicolumn{3}{|c|}{ Heat-flow density } \\
\hline & & & $\begin{array}{l}\text { top } \\
m n\end{array}$ & $\begin{array}{l}\text { bottom } \\
\text { hbsl }\end{array}$ & $\begin{array}{l}\text { top } \\
{ }^{\circ} \mathrm{C}\end{array}$ & $\begin{array}{c}\text { bottom } \\
{ }^{\circ} \mathrm{C}\end{array}$ & & & $q_{i}$ & $\begin{array}{c}\mathrm{q}_{\mathrm{s}} \\
\mathrm{mW} / \mathrm{m}^{2}\end{array}$ & $\mathrm{q}_{20 \mathrm{~km}}$ \\
\hline & & & & & & & & overall mean & $78.9 \pm 5$ & $80.1 \pm 4.9$ & $48.6 \pm 4.5$ \\
\hline \multirow[t]{2}{*}{ Borg-1 } & $08^{\circ} 48^{\prime} 22.9^{\prime \prime}$ & $55^{\circ} 02^{\prime} 57.0^{\prime \prime}$ & -18.4 & 3046.6 & 0 & $84 \pm 4.8$ & $27.7^{1}$ & 1.207 & 69.6 & 70.7 & 41.4 \\
\hline & & & & & & & & mean: & 71.1 & 72.0 & 42.7 \\
\hline \multirow[t]{3}{*}{ Brøns-1 } & $08^{\circ} 44^{\prime} 08.5^{\prime \prime}$ & $55^{\circ} 12^{\prime} 04.1 "$ & -11.0 & 2302.0 & 0 & $82 \pm 8.4$ & $35.8^{1}$ & 0.937 & 87.5 & 87.8 & 55.6 \\
\hline & & & -11.0 & 2264.0 & 0 & 67 & $29.7^{2}$ & 0.927 & 72.3 & 72.7 & 40.4 \\
\hline & & & & & & & & mean: & 79.9 & 80.2 & 48.0 \\
\hline \multirow[t]{2}{*}{ Kegnæs-1 } & $10^{\circ} 05^{\prime} 15.2^{\prime \prime}$ & $54^{\circ} 50^{\prime} 51.2^{\prime \prime}$ & -39.0 & 2536.0 & 0 & $83 \pm 1.9$ & $33.2^{1}$ & 1.013 & 81.9 & 83.0 & 50.6 \\
\hline & & & -39.0 & 1999.0 & 0 & $71 \pm 11$ & $36.2^{1}$ & 0.867 & 81.9 & 82.6 & 50.3 \\
\hline \multirow{2}{*}{ Løgumkloster-1 } & & & -19.0 & 2377.0 & 0 & 76 & $32.2^{2}$ & 0.897 & 84.7 & 85.5 & 53.1 \\
\hline & & & & & & & & mean: & 82.9 & 83.8 & 51.3 \\
\hline \multirow[t]{5}{*}{ Schlesw ig Z1 } & 9³1'25.7" & $54^{\circ} 32^{\prime} 46.2^{\prime \prime}$ & -39.0 & 6061.0 & 0 & 168.2 & $27.9^{3}$ & 2.240 & 75.1 & 78.0 & 48.2 \\
\hline & & & -39.0 & 5510.0 & 0 & 167.3 & $30.6^{3}$ & 2.026 & 82.6 & 85.2 & 55.5 \\
\hline & & & -39.0 & 4595.0 & 0 & 126.5 & $27.8^{3}$ & 1.681 & 75.2 & 77.5 & 47.8 \\
\hline & & & -39.0 & 4029.0 & 0 & 115.7 & $29.0^{3}$ & 1.455 & 79.5 & 81.6 & 51.8 \\
\hline & & & & & & & & mean: & 78.1 & 80.6 & 50.8 \\
\hline Sønderborg-1 & $09^{\circ} 50^{\prime} 24.1 "$ & $54^{\circ} 55^{\prime} 43.7^{\prime \prime}$ & -9.6 & 2402.0 & 0 & 76 & $31.5^{4}$ & 0.990 & 76.8 & 77.9 & 45.5 \\
\hline \multirow[t]{3}{*}{ Varnæs-1 } & $09^{\circ} 35^{\prime} 32.0^{\prime \prime}$ & $55^{\circ} 02^{\prime} 13.0^{\prime \prime}$ & -21.5 & 2201.1 & 0 & $85 \pm 9.2$ & $38.2^{1}$ & 1.033 & 82.3 & 83.0 & 50.2 \\
\hline & & & -21.5 & 1544.1 & 0 & $58 \pm 3.2$ & $37.0^{1}$ & 0.726 & 79.9 & 80.3 & 47.4 \\
\hline & & & & & & & & mean: & 81.1 & 81.7 & 48.8 \\
\hline
\end{tabular}

Note: ${ }^{1}$ BHT corrected by cylindrical-source-method-inversion (CMI), ${ }^{2}$ drill-stem test (DST), ${ }^{3}$ BHT corrected by Horner plot, ${ }^{4}$ loggingwhile-drilling (LWD) 


\section{Thermal model - method, setup and parameterization}

Following the discussion in part one of this study, thermal conduction is assumed to be the dominant mechanism for heat transport, which is expressed in the three-dimensional heat equation by:

$$
\rho c \frac{\partial T}{\partial t}=\frac{\partial}{\partial x}\left(\lambda \frac{\partial T}{\partial x}\right)+\frac{\partial}{\partial y}\left(\lambda \frac{\partial T}{\partial y}\right)+\frac{\partial}{\partial z}\left(\lambda \frac{\partial T}{\partial z}\right)+H .
$$

In this equation, $\rho$ is density $\left[\mathrm{kg} \mathrm{m}^{-3}\right], c$ is specific heat capacity $\left[\mathrm{J}(\mathrm{kg} \mathrm{K})^{-1}\right], \frac{\partial T}{\partial t}$ is the temperature change with time, $\lambda$ is TC $\left[\mathrm{W}\left(\mathrm{m} \mathrm{K}^{-1}\right], H\right.$ is the RHP $\left[\mathrm{W} \mathrm{m}{ }^{-3}\right]$ and $\frac{\partial T}{\partial x}, \frac{\partial T}{\partial y}, \frac{\partial T}{\partial z}$ are the temperature gradients in $\mathrm{x}, \mathrm{y}$, and $\mathrm{z}$ direction, respectively. Under steady-state conditions $\left(\frac{\partial T}{\partial t}=0\right)$, eq. 3 simplifies to:

$-H=\nabla \cdot(\lambda \nabla T)$,

where $\nabla$ is the Nabla operator. Under these conditions, the numerical solution depends only on the rock TC and RHP and the given boundary conditions. We solve eq. 4 numerically using a 3D Finite-Element Method implemented in FEFLOW ${ }^{\circledR} 6.2$ (Diersch, 2014).

Based on structural data from Kirsch et al. (2015) and Maystrenko and Scheck-Wenderoth (2013), 14 major geological units are defined from the surface down to a depth of $20 \mathrm{~km}$. The model includes 13 sedimentary layers of Cenozoic to Pre-Permian ages and one underlying layer representing metamorphic and crystalline basement. These layers define the vertical structural resolution of the modelled geological units. Faults are considered as simple structural offsets. The 14 geological layers are subdivided into 43 numerical FEFLOW layers and represented by $3,719,715$ three-dimensional prismatic mesh elements and 1,913,692 nodes. A Dirichlet boundary condition is set $\left(9{ }^{\circ} \mathrm{C}\right.$ constant $)$ at the Earth's surface, while a constant Neumann boundary condition $\left(48.6 \mathrm{~mW} / \mathrm{m}^{2}\right)$, is set at the model bottom (20 km depth; for details of determination, see section 4.2). The model sides are assumed as no flow boundaries. For further details and discussion on workflow, structure, mesh generation and boundary conditions, see also part one of this study (Fuchs and Balling, 2016, this issue).

Following results of the uncertainty analysis in part one of this study, rock thermal properties are determined from geophysical well-logging data. For bulk TC, borehole profiles are calculated applying the equations of Fuchs et al. (2015). RHP is calculated applying the equations of Rybach (1986) as well as Bücker and Rybach (1996) ( $c f$. part one, section 2.2). Statistical parameters such as the arithmetic mean (am), standard deviation (sd), minimum (min) and maximum $(\max )$ values, $25 \%$ and $75 \%$ quantiles $\left(\mathrm{Q}_{0.25}, \mathrm{Q}_{0.75}\right)$ and the $95 \%$ confidence interval $\left(\mathrm{CI}_{0.95}\right)$ are calculated for each geological unit at each borehole location to 
quantify the spatial variation of the rock thermal properties. Since all well-log data are sampled to the small step of $0.25 \mathrm{~m}$, the application of the arithmetic mean is equal to the lithologicalthickness weighted arithmetic mean. Statistical values of TC and RHP for each modelled unit are summarized in Table 2.

Table 2. Thermal properties of the geological units derived from well logs.

\begin{tabular}{|c|c|c|c|c|c|c|c|c|c|c|c|c|c|}
\hline & \multirow{3}{*}{ Geological units } & \multicolumn{6}{|c|}{ Rock thermal conductivity } & \multicolumn{6}{|c|}{ Radiogenic heat production } \\
\hline & & \multicolumn{6}{|c|}{$\mathrm{W} /(\mathrm{mK})$} & \multicolumn{6}{|c|}{$\mu \mathrm{W} / \mathrm{m}^{3}$} \\
\hline & & $\mathrm{n}$ & mean & SD & $\min$ & $\max$ & $\mathrm{Cl} 95 \%$ & $\mathrm{n}$ & mean & SD & $\min$ & $\max$ & $\mathrm{Cl} 95 \%$ \\
\hline 1 & Quaternary/Tertiary & 23 & 2.5 & 0.5 & 1.6 & 3.4 & 0.2 & 16 & 0.8 & 0.4 & 0.2 & 1.8 & 0.2 \\
\hline 2 & Upper Cretaceous & 25 & 3.1 & 0.5 & 1.9 & 3.7 & 0.2 & 18 & 0.3 & 0.2 & 0.1 & 0.8 & 0.1 \\
\hline 3 & Low er Cretaceous & 25 & 2.3 & 0.5 & 1.3 & 3.2 & 0.2 & 19 & 1.1 & 0.6 & 0.4 & 2.5 & 0.3 \\
\hline 4 & Upper Jurassic & 1 & 2.4 & & 2.4 & 2.4 & & 1 & 0.9 & & 0.9 & 0.9 & \\
\hline 5 & Middle Jurassic & 2 & 1.9 & 0.3 & 1.7 & 2.1 & 0.9 & 3 & 1.2 & 0.1 & 1.1 & 1.3 & 0.2 \\
\hline 6 & Low er Jurassic & 5 & 1.7 & 0.6 & 1.1 & 2.7 & 0.7 & 4 & 1.5 & 0.9 & 0.4 & 2.2 & 1.2 \\
\hline 7 & Upper Keuper (Rhaetian/Gassum) & 12 & 2.2 & 0.6 & 1.3 & 3.0 & 0.4 & 9 & 1.0 & 0.5 & 0.4 & 2.0 & 0.3 \\
\hline 8 & Low er-Middle Keuper & 21 & 2.2 & 0.4 & 1.3 & 3.1 & 0.2 & 17 & 1.3 & 0.7 & 0.1 & 2.8 & 0.4 \\
\hline 9 & Upper Buntsandstein-Muschelkalk & 21 & 2.5 & 0.4 & 1.6 & 3.2 & 0.2 & 16 & 1.1 & 0.5 & 0.5 & 2.2 & 0.3 \\
\hline 10 & Middle Buntsandstein & 19 & 2.4 & 0.6 & 1.5 & 3.5 & 0.3 & 15 & 1.4 & 0.7 & 0.4 & 3.2 & 0.4 \\
\hline 11 & Low er Buntsandstein & 18 & 2.4 & 0.7 & 1.3 & 3.6 & 0.4 & 16 & 1.4 & 0.8 & 0.1 & 3.3 & 0.4 \\
\hline 12 & Zechstein & 13 & 4.4 & 0.9 & 3.2 & 5.8 & 0.6 & 14 & 0.4 & 0.2 & 0.0 & 0.8 & 0.1 \\
\hline 13 & Sedimentary Pre-Zechstein & 7 & 2.6 & 0.6 & 2.0 & 3.8 & 0.5 & 8 & 0.9 & 0.5 & 0.1 & 1.5 & 0.4 \\
\hline 14 & Crystalline Basement & & 3.1 & & 2.8 & 4.4 & & 8 & 1.7 & 1.4 & 0.1 & 4.6 & 1.2 \\
\hline
\end{tabular}

Radiogenic heat production is applied as a constant value for each modelled geological unit (mean value over all borehole observations for each layer), whereas for TC, the spatial variability between the borehole locations is considered. An example of the spatial variability of TC derived from well-specific formation values within the study area is given in Fig. 3 of part one. Several correction approaches are available for the temperature and pressure effect of TC for different rock types (e.g. Anand et al. 1973, Seipold 1990, Abdugalatova et al. 2009, Vosteen and Schellschmidt 2003, Fuchs and Förster, 2014). However, no universally applicable unifying equations are available to date. Since our TC values are determined based on well-log data, such effects are probably partly compensated, when temperature and/or pressure sensitive well logs like neutron, sonic, and density are used. A quantification of such effects is still open. Consequently, we corrected TC only for the temperature effect by applying relations in Somerton (1992) and Zoth and Haenel (1988) and ignored the assumed minor effect of pressure on the rock TC. While a temperature correction for rock salt and quartz-rich sandstone is in particular important, we consider the minor effect of pressure, not compensated by pressure sensitive well logs, to be counterbalanced during the calibration.

Temperature measurements ( $c f$. section 4.1) are used to calibrate the TC and the RHP of the modelled layers. For this purpose, a Gauss-Levenberg-Marquardt algorithm (GLMA) implemented in FePest (Doherty, 2002) is applied to minimize an objective function comprised 
of the weighted sum of squared differences between modelled temperatures and their corresponding borehole measurements (weights applied to the observation explained in section 4.1). Further details to the GLMA are explained in part 1 of this study. The sensitivity of the basal heat flow to the predicted temperature is tested also (testing range: $44-54 \mathrm{~mW} / \mathrm{m}^{2}$ ), but is not included in the final calibration.

\section{Results}

Following the study goal, to quantify the subsurface temperature field of the study area based on the 3D geological model, a detailed parameterization of the rock thermal properties, modelling results and their uncertainties are presented and discussed. The temperature distribution resulting from the 3D thermal Feflow model have been processed in $\operatorname{ArcGIS}^{\odot}$ and are shown in Fig. 7 for the top of geological reservoirs, and in Fig. 8 for constant depth levels.

\subsection{Quantification of uncertainties in temperature prediction}

The quality of the temperature model is mainly determined by the quality of the input data (geological structure, rock thermal properties), and boundary conditions as well as by the quantity and quality of the temperature data used for the model calibration. Final TC values resulting from the calibration are on average slightly higher (mean: $5 \pm 6 \%$ ) than the original input TC values (decreased for four layers, and increased for 10 layers) (Table 3).

Table 3. Calibrated rock thermal conductivity of the geological units.

\begin{tabular}{|c|c|c|c|c|c|c|}
\hline \multirow{3}{*}{ Geological unit } & \multicolumn{4}{|c|}{ Calibrated TC } & \multicolumn{2}{|c|}{ Change to input } \\
\hline & mean & SD & $\min$ & $\max$ & $\Delta$ abs. & $\Delta$ rel. \\
\hline & \multicolumn{4}{|c|}{$\mathrm{W} /(\mathrm{mK})$} & $\overline{\mathrm{W} /(\mathrm{mK})}$ & $\%$ \\
\hline 1 Quaternary/Tertiary & 2.6 & 0.1 & 1.6 & 3.4 & 0.0 & $1 \%$ \\
\hline 2 Upper Cretaceous & 3.0 & 0.3 & 2.0 & 3.7 & -0.1 & $-2 \%$ \\
\hline 3 Low er Cretaceous & 2.2 & 0.4 & 1.3 & 3.2 & -0.1 & $-5 \%$ \\
\hline 4 Upper Jurassic & 3.0 & & 3.0 & 3.0 & 0.6 & $24 \%$ \\
\hline 5 Middle Jurassic & 2.0 & 0.1 & 1.7 & 2.1 & 0.1 & $6 \%$ \\
\hline 6 Low er Jurassic & 1.7 & 0.3 & 1.3 & 2.6 & 0.0 & $1 \%$ \\
\hline 7 Upper Keuper (Rhaetian/Gassum) & 2.1 & 0.5 & 1.3 & 2.9 & -0.1 & $-4 \%$ \\
\hline 8 Low er-Middle Keuper & 2.5 & 0.4 & 1.7 & 3.1 & 0.3 & $15 \%$ \\
\hline 9 Upper Buntsandstein-Muschelkalk & 2.8 & 0.3 & 1.6 & 3.2 & 0.3 & $11 \%$ \\
\hline 10 Middle Buntsandstein & 2.5 & 0.4 & 1.5 & 3.4 & 0.2 & $7 \%$ \\
\hline 11 Low er Buntsandstein & 2.6 & 0.4 & 1.3 & 3.6 & 0.2 & $9 \%$ \\
\hline 12 Zechstein & 4.9 & 0.5 & 3.4 & 5.8 & 0.5 & $12 \%$ \\
\hline 13 Sedimentary Pre-Zechstein & 2.7 & 0.2 & 2.3 & 2.9 & 0.1 & $4 \%$ \\
\hline \multirow[t]{4}{*}{14 Crystalline Basement } & 3.2 & 0.2 & 2.8 & 3.4 & 0.1 & $4 \%$ \\
\hline & \multicolumn{4}{|c|}{ absolute mean: } & 0.20 & $7 \%$ \\
\hline & \multicolumn{4}{|c|}{ absolute sd: } & 0.18 & $6 \%$ \\
\hline & \multicolumn{4}{|c|}{ median: } & 0.12 & $5 \%$ \\
\hline
\end{tabular}

A comparison of temperatures observed at known xyz-positions of boreholes with those computed by the numerical model at the same coordinates helps to quantify the uncertainties of 
the modelled temperature field. For this evaluation, measured temperature data from 24 wells located in different structural domains are used ( $c f$. section 4.1).

For the final model, a very good agreement between measured and modelled temperatures can be observed. The rms error amounts to $3.5{ }^{\circ} \mathrm{C}$ (corresponding to an $\mathrm{rms}$ of $4.7 \%, \mathrm{n}=59$ ), whereas the (absolute) arithmetic mean error is $2.1 \pm 2.9{ }^{\circ} \mathrm{C}$ (equal to an ame of $2.9 \%$ ). For more than $50 \%$ of the compared temperature data, deviations are less than $1{ }^{\circ} \mathrm{C}$; another $30 \%$, show deviations less than $5{ }^{\circ} \mathrm{C}$ (Fig. 5). Only for two observations (out of 59), a relatively poor fit with deviations larger than $10 \%$ is observed. Temperature observation of highest accuracy are available from the temperature profile logged in the Sønderborg well. On each depth point of the well, predictions show very small deviations $\left(<<1{ }^{\circ} \mathrm{C}\right)$ compared with the measured temperatures (Fig. 6).

The agreement between measured and modelled temperatures is tested also for varying basal heat flow values. The best-fit basal heat flow of $45 \mathrm{~mW} / \mathrm{m}^{2}$ only results in an insignificant reduction (paired $t$-test, $\mathrm{n}=59, \mathrm{p}=0.152$ ) of the deviations between measured and modelled temperatures $\left(\mathrm{rms}=3.3{ }^{\circ} \mathrm{C}\right)$. This led us to the conclusion that, as outlined above for the pressure effect on TC, a further adjustment of the basal HF is not required and would be additionally compensated by adjusting the TC values during the calibration.
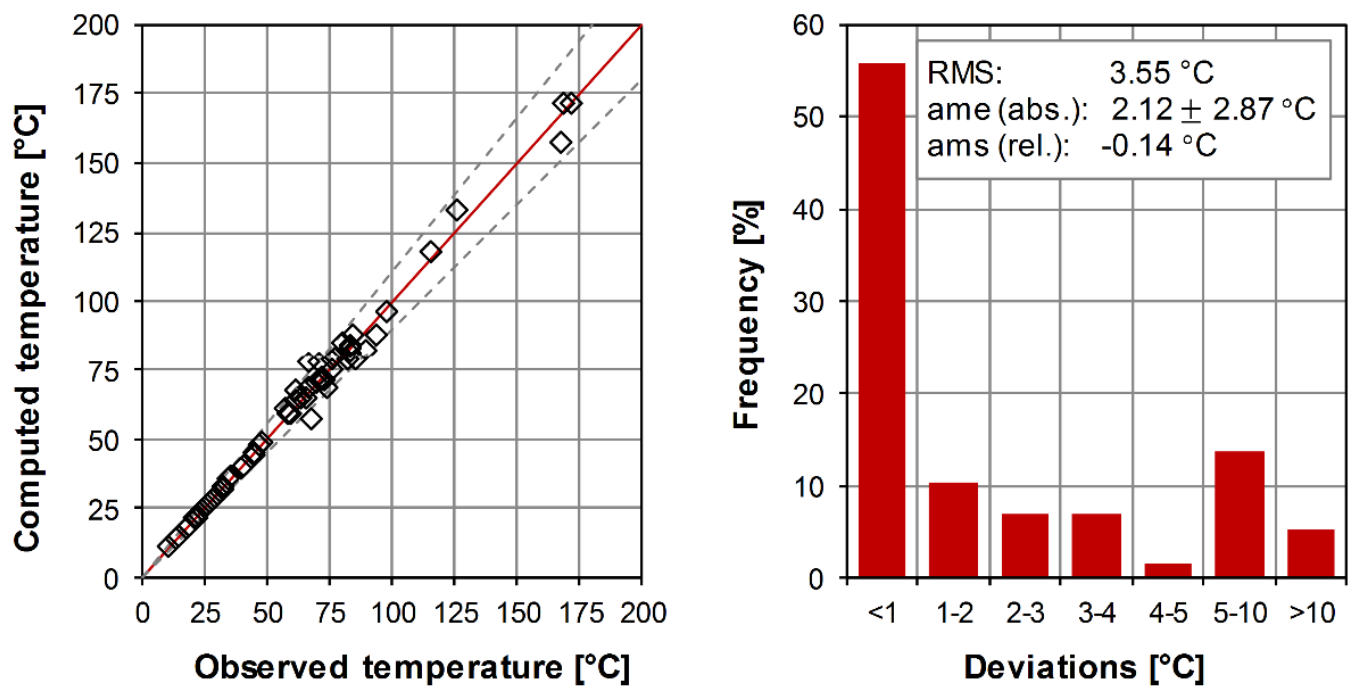

Figure 5. Comparison between modelled and observed borehole temperatures. 


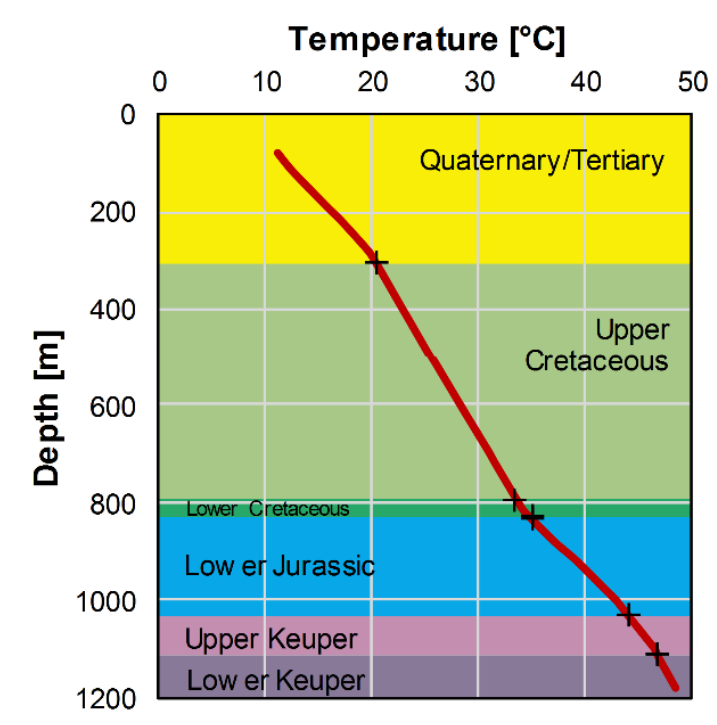

Figure 6. Comparison of modelled (black crosses) and logged (red line) temperatures at the Sønderborg well (continuous equilibrium temperatures).

\subsection{Modelled subsurface temperatures}

The modelled subsurface temperature field shows large lateral and vertical variations across the study area. As an illustration, temperatures modelled at the top of the Rhaetian/Gassum Formation and the Middle Buntsandstein (Fig. 7) show a general North-to-South trend with temperatures increasing from 23 to $161{ }^{\circ} \mathrm{C}$ and from 24 to $192{ }^{\circ} \mathrm{C}$, respectively. The highest temperatures are observed in the troughs of the Glückstadt Graben, whereas the lower values are observed from the NW-SE trending Tфnder Graben and northwards. Temperatures larger than $120^{\circ} \mathrm{C}$, technically suitable for the generation of electricity, are observed only at the very southern margin of the study area. For the top of both geological units (Rhaetian/Gassum and the Middle Buntsandstein), temperatures in the area of the West-Schleswig block are relatively homogenous, ranging in a small band between 50 and $60{ }^{\circ} \mathrm{C}$, and between 70 and $90{ }^{\circ} \mathrm{C}$, respectively, and thus deviating from the above general trend.

At a depth of $1 \mathrm{~km}$ ( $c f$. Fig. 8), the temperatures range observed from the modelling is between 29 and $57{ }^{\circ} \mathrm{C}$, resulting in average temperature gradients between 20 and $48{ }^{\circ} \mathrm{C} / \mathrm{km}$. Temperatures above $45^{\circ} \mathrm{C}$ are found only in the Glückstadt Graben, and temperatures above $50{ }^{\circ} \mathrm{C}$ are always associated to Zechstein salt structures (depending on the xy-coordinates, the $1-\mathrm{km}$ level is above, within or below the rock salt). The troughs between the salt walls show temperatures that are reduced by 10 to $20{ }^{\circ} \mathrm{C}$ compared with salt structures at the same depth level. Temperatures in the area of the West-Schleswig block are relatively homogenous, mainly ranging between 35 and $40{ }^{\circ} \mathrm{C}$. 
For the 2-km depth level, observed temperatures ranges between 49 and $91{ }^{\circ} \mathrm{C}$, corresponding to average temperature gradients of 20 to $41{ }^{\circ} \mathrm{C} / \mathrm{km}$. Highest temperatures $\left(>80^{\circ} \mathrm{C}\right)$ and lowest temperatures $\left(<60{ }^{\circ} \mathrm{C}\right)$ are still related to the salt structures and troughs of the Glückstadt Graben. Again, the West-Schleswig block shows relatively small variations $\left(61-70{ }^{\circ} \mathrm{C}\right)$, and relatively higher temperatures $\left(>75^{\circ} \mathrm{C}\right.$ ) are observed north of the Tønder Graben (up to $79^{\circ} \mathrm{C}$ ). The temperatures at the 3-km depth level are ranging between 75 and $117^{\circ} \mathrm{C}$ (mainly between 85 and $100{ }^{\circ} \mathrm{C}$ ), indicating average temperature gradients between 22 and $36^{\circ} \mathrm{C} / \mathrm{km}$. The trend of increasing temperatures at the positions of the salt structures, obvious for the $1 \mathrm{~km}$ and $2 \mathrm{~km}$ level, is absent. The highest temperatures $\left(>105^{\circ} \mathrm{C}\right)$ are now located at the northern margins of the troughs in the Glückstadt Graben, whereas at the positions of the salt structures temperatures are reduced by $c .5{ }^{\circ} \mathrm{C}$ compared with the surrounding sediments. A trend of increasing temperatures from the Tønder Graben northwards is also apparent.

At the $5 \mathrm{~km}$ depth level, the association of temperatures anomalies with salt structures, as observed at the shallow depth in the Glückstadt Graben, is completely reversed. Temperatures in the troughs are typically 10 to $15{ }^{\circ} \mathrm{C}$ higher than in surrounding areas with salt structures. Temperatures at that depth level are generally ranging between 112 and $168{ }^{\circ} \mathrm{C}$; values $>150$ ${ }^{\circ} \mathrm{C}$ occur only in the trough in the very southeastern part of the model domain. Temperatures below $130{ }^{\circ} \mathrm{C}$ are mainly observed in the southwestern part, and the trend of increasing temperatures towards and across the Tonder Graben in north-easterly direction is becoming more apparent.

Temperature maps for deeper depth level are not shown as both boreholes that provide input data and measured temperatures for the calibration are limited to the upper maximum six kilometre. No detailed lithological observations on the deeper structure and the variations of thermal properties are available. However, our models may still yield some information on the general trends of temperature variations (Fig. 9). The modelled temperature pattern at a depth of $10 \mathrm{~km}$ (range: $235-276{ }^{\circ} \mathrm{C}$ ) is still influenced by the overlaying salt structures and thick sediments in the Glückstadt Graben. Below the graben, some elevation of temperatures, due to the very thick sequence of relatively low-conductivity sediments, can be seen down to the deepest part of the model. However, temperatures at the model base does not correlate with the thickness distribution of the salt rocks anymore. 
Top Rhaetian/Gassum formation

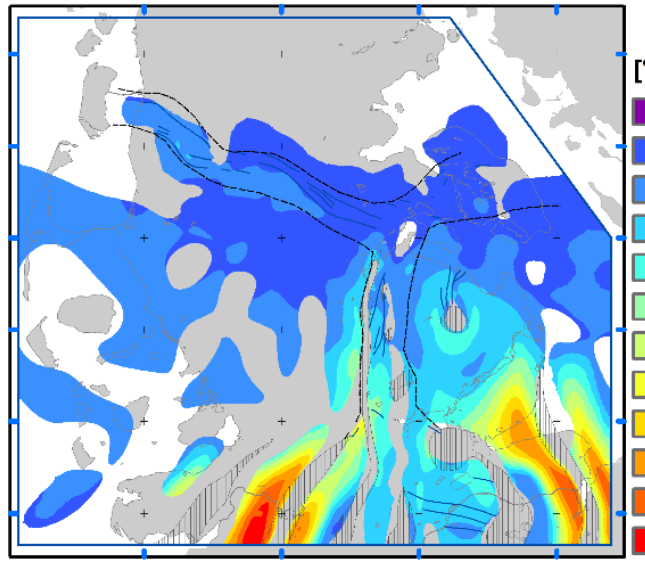

Top Middle Buntsandstein

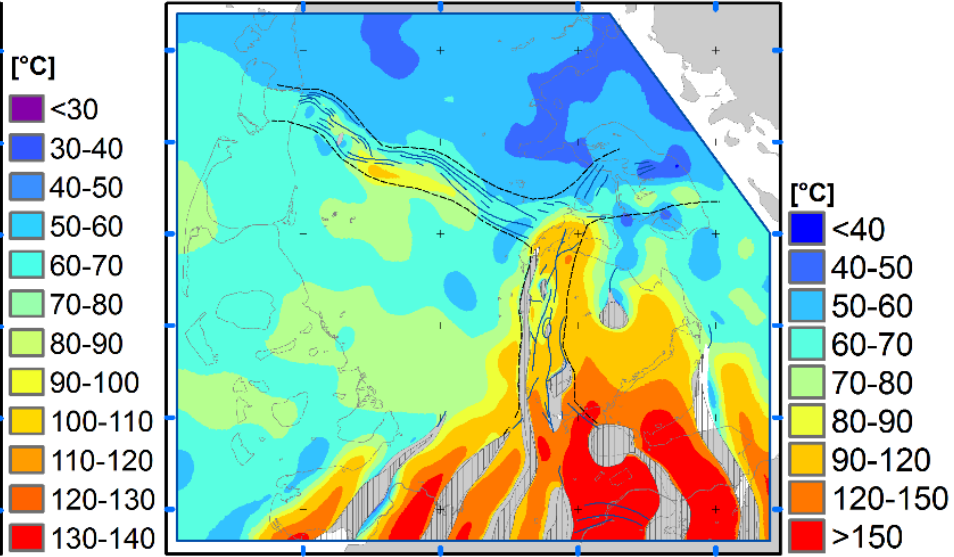

Figure 7. Modelled temperature distribution at the top of Rhaetian/Gassum Formation (left) and of Middle Buntsandstein (right).
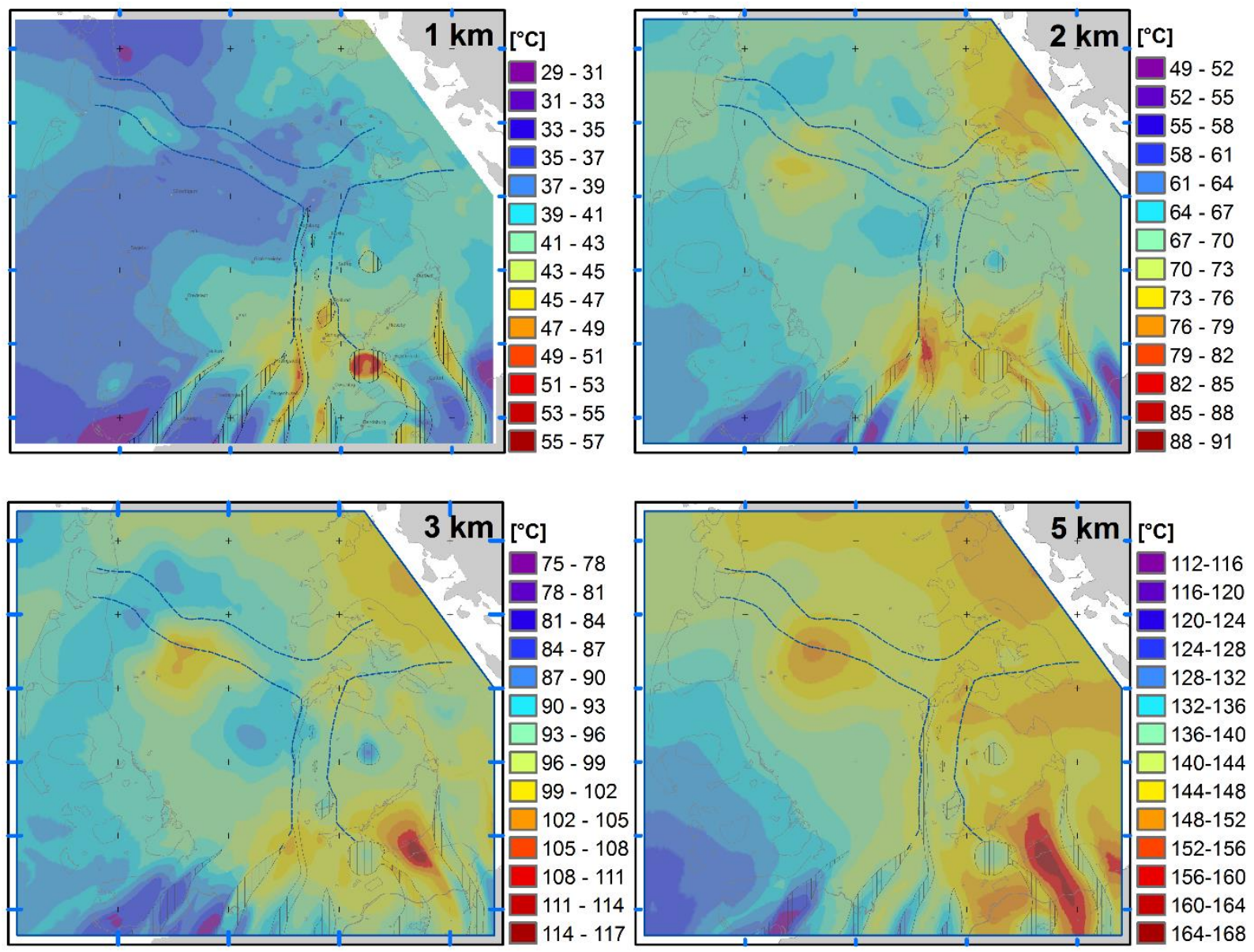

Figure 8. Modelled temperature distribution for selected constant depth level (depth below sea level). Dashed line indicate trend of major fault system and hatched areas show major salt structures (walls and diapirs). 


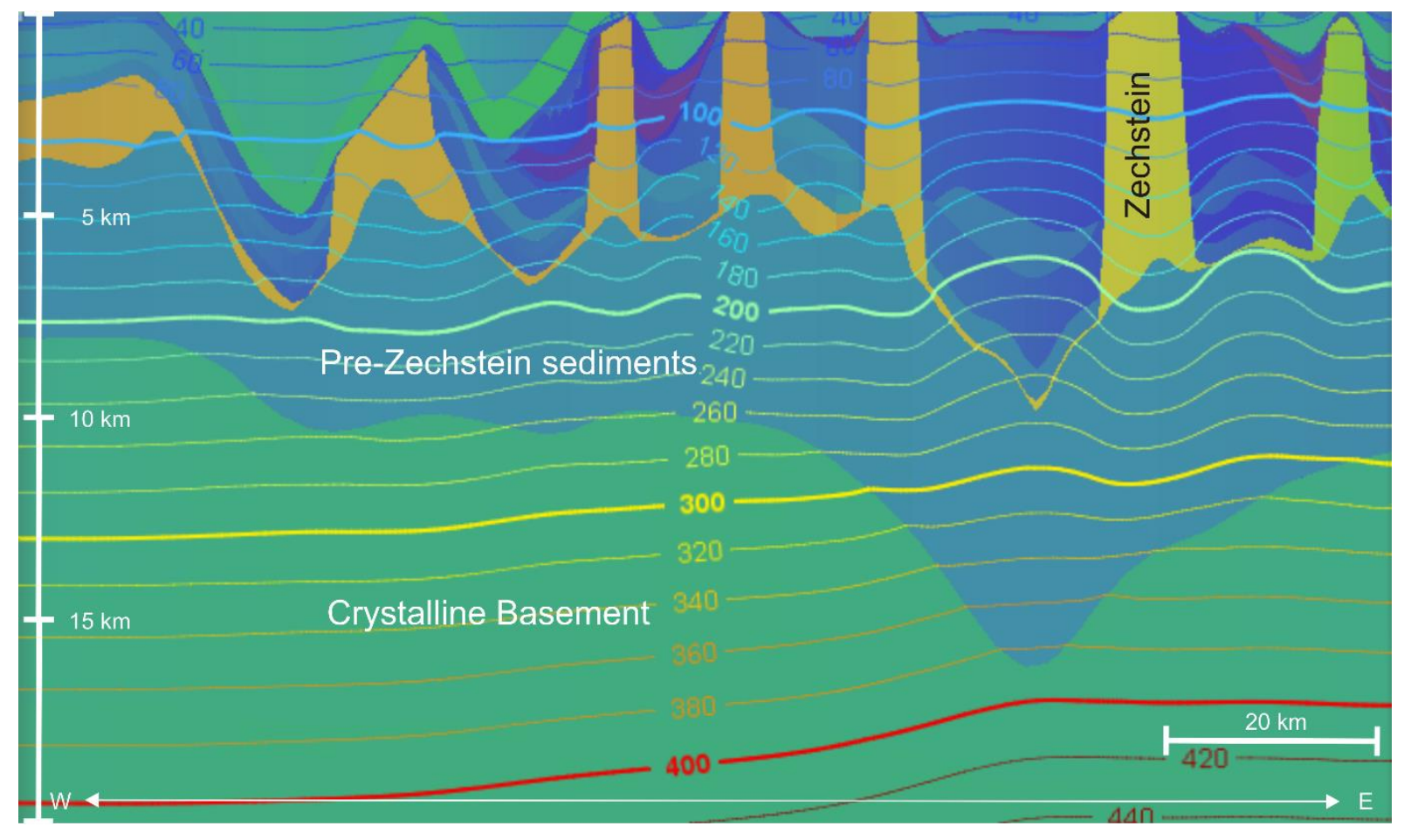

Figure 9. Modelled temperature distribution (isotherms) along the EW section on the southern border of the study area. Variations in thermal conductivity are associated with the different lithostratigraphic units indicated by colour shading.

\subsection{Modelled surface heat flow}

Modelled surface heat flow in the 3D model range between 60 and $115 \mathrm{~mW} / \mathrm{m}^{2}$ across the study area (Fig. 10). The overall mean value is $80.7 \pm 6.1 \mathrm{~mW} / \mathrm{m}^{2}$. High values, above $95 \mathrm{~mW} / \mathrm{m}^{2}$, are always associated with underlying salt structures and thus mostly found in the Glückstadt Graben area. Similarly, are the lower values (less than $70 \mathrm{~mW} / \mathrm{m}^{2}$ ) mainly in the troughs of the Glückstadt Graben. The remaining areas (Westschleswig Block and East-Holstein Block) show consistent values of 80 to $85 \mathrm{~mW} / \mathrm{m}^{2}$. A slight increase in surface heat flow to around and slightly above $85 \mathrm{~mW} / \mathrm{m}^{2}$ is found in regions north of the Tønder Graben. Modelled and measured $q_{\mathrm{s}}$ show a reasonable agreement (Fig. 10) where the mean values of both groups differ insignificantly by ca. $3 \%(\mathrm{n}=8$, independent student $t$-test, $\mathrm{p}>0.055)$. 


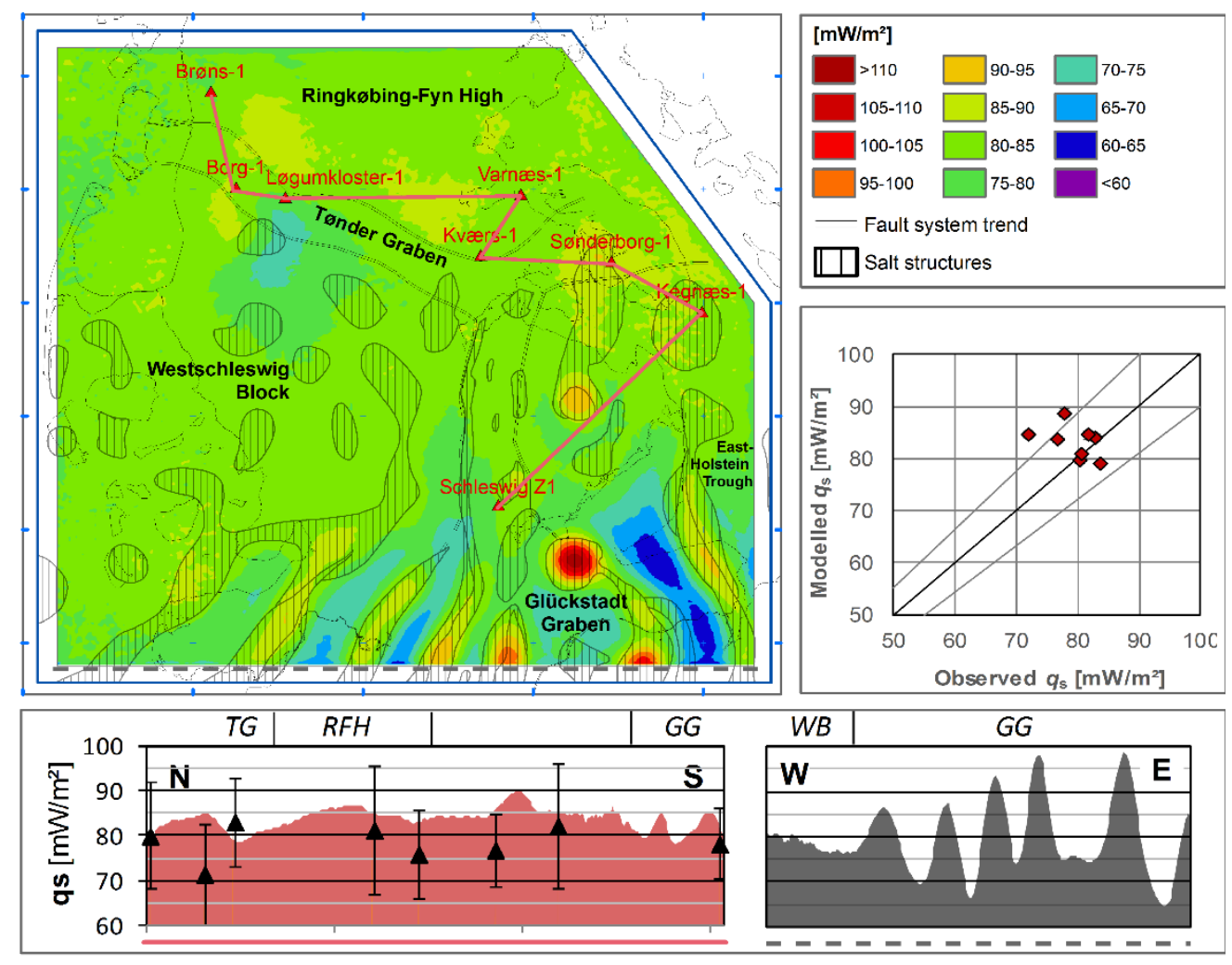

Figure 10. Top, left: Modelled surface heat flow $q_{s}$ (in $\mathrm{mW} / \mathrm{m}^{2}$ ). Well locations along the pink line (170 km length) are used for heat-flow observations ( $c f$. Table 1). Middle right: Comparison of modelled and observed heat flow (in boreholes). Bottom: Heat-flow profiles along the pink solid line (NW-SE) and the dark grey dashed line (E-W, southernmost margin of the study area). Location of both lines are indicated in the $q_{\mathrm{s}}$ map (top left).

\section{Discussion}

\subsection{Quality of the temperature model}

The small prediction uncertainties observed for the temperature model are mainly achieved by considering the spatial variation of TC as well as by calibrating the model with a good-quality temperatures data set. A well-constrained lower heat-flow boundary condition, based on several borehole observations, is of additional value. Adjusting TC and RHP values (in a small reasonable range of 1-sd) in the calibration, by iteratively minimizing the misfit between observed and modelled temperatures, significantly improved the quality of the temperature predictions. The difference between initial and final TC data set is on average around 5\% (8\% absolute) $[0.21 \mathrm{~W} /(\mathrm{mK})]$. This small value is most likely related to the good quality well-log based TC input data. In boreholes where both information of well-log derived rock TC and measured temperatures have been available ( $c f$. Fig. 1), computed deviations to modelled temperatures are usually quite small $\left(<1{ }^{\circ} \mathrm{C}\right)$. Clearly, such small temperature deviations are unrealistic in general, as the majority of the calibration data set consists of corrected BHT 
values, most of them having an uncertainty (sd) of about or larger than $5{ }^{\circ} \mathrm{C}$. Even CMIcorrected BHT's that show a very small uncertainty $\left(\mathrm{sd}: 1-5^{\circ} \mathrm{C}\right)$ implement larger errors than reflected in the small average prediction uncertainty of the presented temperature model. The uncertainties of the model temperature predictions are unlikely to be smaller than the uncertainties of the implemented calibration temperatures. This is also reflected in the, still, relatively small differences between modelled and observed surface heat flow, generally within the uncertainty of determinations (Table 1 and Fig.10). Nevertheless, the small deviations between computed and observed temperatures demonstrate the strength of a calibrated thermal model parameterized by reliable heat-flow data and a detailed analysis of the spatial variation of rock TC.

A borehole with a larger misfit is Schwedeneck 20, which is located very close to the western flank of a salt structure in the southwestern part of the study area (close to Schwedeneck 29, Fig. 1). Model volumes within and close to salt structures generally have among the higher uncertainties. Difficulties in accurate modelling, in particular the over-hanging parts of diapirs or salt walls with the applied 3D-prismatic model elements, may be the main reason. Furthermore, uncertainty of the input geological model is generally higher in such areas of complex structural conditions and highly dependent on local seismic profile coverage. The majority of borehole data included in this study cover depth down to around $3 \mathrm{~km}$, and only some few boreholes provide data to depth of around $6 \mathrm{~km}$. Below these depth, and in areas where little or no information on TC or measured temperatures are available, uncertainties are expected to be higher than those illustrated in Fig. 5 for areas constrained by data.

\subsection{Differences compared with previous studies}

Important previous thermal modelling studies in the study area have been carried out by Rodon and Littke (2005) and by P. Balling et al. (2013). Compared with these studies, the present work is based on a detailed parameterization of the rock thermal properties and is constrained by data from much more boreholes. This improved input database is reflected in the excellent fit between modelled and measured temperatures. P. Balling et al. (2013) have used measured temperatures from six wells for validation, from which two wells are located in our study area (Schleswig Z1, and Flensburg Z1). However, for both wells insufficient temperature information are available (Horner-corrected or uncorrected BHT's) and these wells/data are excluded from our study. Generally, the mean temperature misfit (ame) of $2.1^{\circ} \mathrm{C}$ found in this study is significantly lower than the ame of $c .10{ }^{\circ} \mathrm{C}$ found by P. Balling and co-workers (Phillip Balling, personal communication, 2014). As we have used the same basic modelling approach, 
this result seems caused by the different parameterization technique and better data constraints. Considering the spatial variation of the formation TC derived from well data, against laterally constant formation values, obviously reflects the natural heterogeneity of this parameter far better and is consistent with observations ( $c f$. Norden and Förster, 2006; Schütz et al., 2012a,b; Homuth et al., 2014). In that respect, our results are generally consistent with results from Vogt et al. (2010) and Mottaghy et al. (2011). They showed that considering the spatial distribution of TC (using a stochastic modelling approach with realizations of TC probability distributions) combined with a constraining post-processing procedure (calibration on temperatures) helps to significantly reduce temperature uncertainties (more than 50\%) compared with the use of homogeneous layer values.

In addition to, and integrated with the temperature predictions, new heat-flow determinations (interval, surface and model base) are important result of this study. Rodon and Littke (2005) presented present-day heat-flow values for six wells, calculated for stratigraphic intervals. They reported $q_{\mathrm{i}}$-values between 45 and $60 \mathrm{~mW} / \mathrm{m}^{2}$ with an average of $52 \pm 6 \mathrm{~mW} / \mathrm{m}^{2}$. Taking into account the RHP of the overlying sedimentary units, we calculated surface heat-flow values ranging between 50 and $67 \mathrm{~mW} / \mathrm{m}^{2}$ (mean: $60 \pm 7 \mathrm{~mW} / \mathrm{m}^{2}$ ), which is significantly lower than our values with an observed mean value of $80.1 \pm 4.9 \mathrm{~mW} / \mathrm{m}^{2}$ (nine boreholes, Table 1) and a modelled mean value of $80 \mathrm{~mW} / \mathrm{m}^{2}$ (model result, Fig. 5). The much lower results of Rodon and Littke might result either from the implementation of uncorrected BHT's or/and from using BHT values measured at shallow depth, which are palaeoclimatically perturbed. The lower average heat flow of $67.4 \pm 7.1 \mathrm{~mW} / \mathrm{m}^{2}$, which we have calculated for the uncorrected BHT data set (by including the RHP) supports this assessment.

\subsection{Temperature and heat-flow field}

The large vertical and lateral temperature variations, observed in the model area, mainly result from regional and local geological variability and associated differences in thermal conductivity Deep background heat flow seems not to vary significantly (cf. Table 1) and is modelled as constant, and is not introducing lateral variations. The crystalline units of the Ringkøbing-Fyn High, located at shallow depths in the northern part, have lower temperatures than the thick sedimentary succession of the Glückstadt Graben to the southeast. Here, the structure of the salt features clearly dominates the modelled temperature variations and anomalies. Positive anomalies are located above or in the upper parts of salt structures (high conductivity of the rock salt and anhydrite), whereas negative anomalies are located between or below such structures (lower conductivity of the mainly clastic and carbonate sediments) (Fig 9). This 
observation is referred as chimney effect and is a characteristic feature for salt structures ( $c f$. model results in Balling et al. 1981; Jensen, 1983, 1990). Our models show temperature anomalies of +15 to $-30{ }^{\circ} \mathrm{C}$. P. Balling et al. (2013) modelled anomalies of similar size. The higher temperatures in deep sedimentary troughs, compared with surrounding areas of rock salt or crystalline rocks, are caused by the lower conductivity of the thick sediments resulting in higher temperature gradients, the well-known thermal blanketing effect also seen in Fig. 9.

The weak trend of increasing modelled surface heat flow North of the Tonder-Graben may be caused by the additional radiogenic heat production resulting from the thicker crystalline crust compared with the southern parts of the modelled area. The RHP of the crystalline crust is estimated to be at least 0.5 to $0.7 \mu \mathrm{W} / \mathrm{m}^{3}$ higher than the average RHP of the overlaying sedimentary section. For 5 to $10 \mathrm{~km}$ extra thickness of crystalline crust, this yields a contribution to surface heat flow of around 3 to $7 \mathrm{~mW} / \mathrm{m}^{2}$. This is consistent with the model results in that region, which show characteristic surface heat flow at around $85 \mathrm{~mW} / \mathrm{m}^{2}$, slightly higher than the modelled average $q_{\mathrm{s}}$ south of the Tonder Graben at around $80 \mathrm{~mW} / \mathrm{m}^{2}$ (cf. Fig. $10)$.

Both our observed and modelled present-day surface heat flow average consistently very close to $80 \mathrm{~mW} / \mathrm{m}^{2}$, which is in very good agreement with reliable determinations from other areas of the North German Basin. For the northeastern part of the basin (German areas), Norden et al., 2008 reported a mean value of $77 \pm 3 \mathrm{~mW} / \mathrm{m}^{2}$ from 13 deep borehole observations (range $68-91 \mathrm{~mW} / \mathrm{m}^{2}$ ). From the same region, Fuchs and Förster, 2010 obtained $76 \mathrm{~mW} / \mathrm{m}^{2}$ for a borehole at Stralsund, and further west, and south of our study area, Orilski et al., 2010 found a value of $82 \mathrm{~mW} / \mathrm{m}^{2}$ for their Hannover location.). These published heat-flow values are all based on data from high precision, continuous temperature logs and laboratory measurements of rock TC and to be considered as highly feasible. We also note that Balling (1992), in his determinations and summary of heat-flow values from the Danish region, includes three deep boreholes from south of the Ringkøbing-Fyn High with surface heat flow (corrected for palaeoclimate) within the narrow range of $79-82 \mathrm{~mW} / \mathrm{m}^{2}$, two of which (Løgumkloster-1 and Varnæs-1) are identical with boreholes with new independent and better TC-determinations in the present study.

For the model base at $20 \mathrm{~km}$, a heat flow mean of $48.6 \pm 4.5 \mathrm{~mW} / \mathrm{m}^{2}$ is obtained from extrapolated borehole observations (Table 1). The radiogenic heat production for the crystalline crust between model base and top of lower crust rocks (depth approximated from data of Maystrenko and Scheck-Wenderoth, 2013) is $1.7 \mu \mathrm{W} / \mathrm{m}^{3}$ (Table 2). The radiogenic heat production for the remaining lower crustal rocks down to the approximated depth of the Moho 
discontinuity at around $30 \mathrm{~km}$ (with crustal P-wave velocities in the range of $6.4-6.9 \mathrm{~km} / \mathrm{s}$, Thybo, 2001; range of 28 to $33 \mathrm{~km}$ according to data from Maystrenko and Scheck-Wenderoth, 2013)) is likely to be low, on average perhaps around $0.4 \mu \mathrm{W} / \mathrm{m}^{3}$ ( $c f$. Balling, 1995; Norden et al. 2008). This results in an estimate of heat flow at the crust-mantle boundary of $33-40 \mathrm{~mW} / \mathrm{m}^{2}$ (q1-q3; mean: $37 \pm 7$. This fits very well the model values of $35-40 \mathrm{~mW} / \mathrm{m}^{2}$ obtained both in Balling (1995), for a profile section crossing very close to our study region, and in Norden et al. (2008) for the eastern part of the North German Basin.

\section{CONCLUSIONS}

A 3D numerical crustal temperature model has been developed for the Danish-German border region in the North German Basin. The modelling approach is novel as it implements for the first time a comprehensive analysis of well-log data on a regional modelling scale. It integrates local petrophysical and temperature observations in the frame of a 3D structural model. Using input parameters (rock thermal properties and heat flow) fully based on well-log data and considering the spatial distribution of rock TC across the study area, form key elements for achieving the observed small temperature prediction uncertainties when comparing observed and modelled temperatures at deep borehole sites $\left(\mathrm{rms}=3.5^{\circ} \mathrm{C}\right.$, ame $=2.1^{\circ} \mathrm{C}$ ).

Pronounced lateral temperature variations are predicted and found to be caused mainly by complex geological structures, including a large amount of salt structures and marked lateral variations in the thickness of basin sediments. The associated variations in rock thermal conductivity generate significant variations in model heat flow and large variations in temperature gradients.

With regard to the utilization of geothermal energy, the Rhaetian and the Middle Buntsandstein sandstone reservoirs are found with temperatures within the range of $40-80^{\circ} \mathrm{C}$, suitable for low enthalpy heating purposes in most of the area and locally also with higher temperatures. Temperatures above $120^{\circ} \mathrm{C}$, of interest for the production of electricity, are observed only in the very southeastern part of the study area. Together with information on reservoir hydraulic properties etc., the presented temperature model will constitute a base for planning and management the subsurface geothermal resources and help preventing conflicts of use in the Danish-German border region.

New heat-flow values obtained for eight deep boreholes, combined with the modelling results, clearly strengthen the view of a relatively high regional surface heat flow of around $80 \mathrm{~mW} / \mathrm{m}^{2}$ in most of the North German Basin, and with $c .40 \mathrm{~mW} / \mathrm{m}^{2}$ originating from the uppermost 
mantle ( $c f$. Balling, 1992, 1995; Norden et al. 2008). Using carefully corrected BHT values and DST data from depth below $1.5 \mathrm{~km}$ (palaeoclimatically not or only to minor extent perturbed) results in good quality heat-flow data, that are up to $20 \mathrm{~mW} / \mathrm{m}^{2}$ higher than low values reported in some previous studies.

\section{ACKNOWLEDGMENTS}

This work was performed in the framework of the INTERREG4A GeoPower project, funded by the European Union (project \#: 89-2.3-11). This study was also supported by the Danish Council for Strategic Research, (geothermal energy, project 2104-09-0082). Project coordination by, and discussions with Reinhard Kirsch (LLUR, GeoPower) and Lars Henrik Nielsen (GEUS) are gratefully acknowledged. We are grateful to the Geological Survey of Denmark (GEUS), the Landesamt für Landwirtschaft, Umwelt und ländliche Räume des Landes Schleswig-Holstein (LLUR) and to the Wirtschaftsverband Erdöl- und Erdgasgewinnung (WEG) for providing the structural geological model (GEUS and LLUR) as well as background data from boreholes, logging data and core material. Digitization of paper prints were performed at the Aarhus University and at the University of Kiel, and we wish to thank in particular Mikkel Klahn, Sandra Michelis, Kerstin Meier zu Beerentrup and Thue S. Bording who supported this work. Yuri Maystrenko and Magdalena Scheck-Wenderoth are thanked for providing structural data of the Pre-Zechstein of the modelled area. The authors would like to thank Volker Rath (Dublin) and one further anonymous reviewer who helped to considerably improve the paper with their constructive feedback.

\section{REFERENCES}

Abdulagatova, Z.Z., Abdulagatov, I.M., Emirov, S.N., 2009. Effect of temperature and pressure on the thermal conductivity of sandstone, International Journal of Rock Mechanics and Mining Sciences, 46, 1055-1071.

Anand, J., Somerton, W.H., Gomaa, E., 1973. Predicting thermal conductivities of formations from other known properties SPE J., 13, 267-272.

Balling, N., 1979. Subsurface temperatures and heat flow estimates in Denmark. In: Cermák, V. and Rybach, L. (eds.), Terrestrial Heat Flow in Europe, Springer-Verlag, Berlin, 161171.

Balling, N., 1992. Denmark, in: E. Hurtig, V. Čermák, R. Haenel, V. Zui (Eds.) Atlas of Geothermal Resources in Europe, Hermann Haack Verlagsgesellschaft, Hannover, Germany, pp. 25-28. 
Balling, N., 1995. Heat flow and thermal structure of the lithosphere across the Baltic Shield and northern Tornquist Zone. Tectonophysics, 244, 13-50.

Balling, N., Bording, T.S., 2013. Temperatur, temperaturgradienter og varmeledningsevne i den geotermiske boring Sønderborg-1/1A.Research report, Department of Geoscience, Aarhus University, Denmark, 16 pp.

Balling N., Hvid, J.M., Mahler, A., Møller, J.J., Mathiesen, A., Bidstrup, T. and Nielsen, L.H., 2002. Denmark. In: Hurter, S. and Haenel, R. (Eds.), Atlas of Geothermal Resources in Europe. Publication No. EUR 17811 of the European Commission, 27-28 and plates 15-16.

Balling, N., Kristiansen, J.I., Breiner, N., Poulsen, K.D., Rasmusen, R., Saxov, S., 1981. Geothermal measurements and subsurface temperature modelling in Denmark, GeoSkrifter, 16, $172 \mathrm{pp}$.

Balling, P., Maystrenko, Y.P., Scheck-Wenderoth, M., 2013. The deep thermal field of the Glueckstadt Graben, Environmental Earth Sciences. 70, 3505-3522.

Bayer, U., Scheck, M., Koehler, M., 1997. Modeling of the 3D thermal field in the northeast German basin, Int J Earth Sci, 86 (1997) 241-251.

Bayer, U., Grad, M., Pharaoh, T.C., Thybo, H., Guterch, A., Banka, D., Lamarche, J., Lassen, A., Lewerenz, B., Scheck, M., Marotta, A.M., 2002. The southern margin of the East European Craton: New results from seismic sounding and potential fields between the North Sea and Poland, Tectonophysics, 360, 301-314.

Benek, R., Kramer, W., McCann, T., Scheck, M., Negendank, J.F.W., Korich, D., Huebscher, H.D., Bayer, U., 1996. Permo-Carboniferous magmatism of the Northeast German Basin, Tectonophysics, 266, 379-404.

Bergerat, F., Angelier, J., Andreasson, P.-G., 2007. Evolution of paleostress fields and brittle deformation of the Tornquist Zone in Scania (Sweden) during Permo-Mesozoic and Cenozoic times, Tectonophysics, 444, 93-110.

Blöcher, G., Zimmermann, G., Moeck, I., Brandt, W., Hassanzadegan, A., Magri, F., 2010. 3D numerical modeling of hydrothermal processes during the lifetime of a deep geothermal reservoir, Geofluids, 10 (2010) 406-421.

Bücker, C., Rybach, L., 1996. A simple method to determine heat production from gamma-ray logs, Marine and Petroleum Geology. 13, 373-375.

Bullard, E.C., 1939. Heat Flow in South Africa, Proceedings of the Royal Society of London. Series A. Mathematical and Physical Sciences, 173, 474-502.

Cacace, M., Kaiser, B.O., Lewerenz, B., Scheck-Wenderoth, M., 2010. Geothermal energy in sedimentary basins: What we can learn from regional numerical models, Chemie der Erde Geochemistry. 70, Supplement 3, 33-46.

Diersch, H.-J., 2014. FEFLOW - Finite Element Modeling of Flow, Mass and Heat Transport in Porous and Fractured Media, Springer, 996 pp.

Doherty, J., 2002. Manual for PEST, 5th edition. Watermark Numerical Computing, Brisbane, Australia.

Friberg, L.J., Poelchau, H.S., Krooss, B., Littke, R., 2000. 3D-modelling of thermal history and simulation of methane and nitrogen migration along the Northeast German seismic DEKORP profile 9601, J. Geochem. Explor, 69-70 (2000) 263-267.

Fuchs, S., Balling, N., 2016. Improving the temperature predictions of subsurface thermal models by using high-quality input data. Part 1: Uncertainty analysis of the thermalconductivity parameterization, Geothermics, 64, this issue, 42-54. 
Fuchs, S., Balling, N., Förster, A., 2015. Calculation of thermal conductivity, thermal diffusivity and specific heat capacity of sedimentary rocks using petrophysical well logs. Geophysical Journal International. 203, 1977-2000.

Fuchs, S., Förster, A., 2010. Rock thermal conductivity of Mesozoic geothermal aquifers in the Northeast German Basin, Chem Erde-Geochem. 70, 13-22.

Fuchs, S., Förster, A., 2014. Well-log based prediction of thermal conductivity of sedimentary successions: a case study from the North German Basin, Geophysical Journal International. 196, 291-311.

Haenel, R., 1980. The subsurface temperature atlas of the European communities, Eos, Transactions American Geophysical Union, 62, pp. 226.

Henk, A., 1999. Did the Variscides collapse or were they torn apart?: A quantitative evaluation of the driving forces for postconvergent extension in central Europe, Tectonics, 18, 774792.

Homuth, S., Götz, A.E., Sass, I., 2014. Lithofacies and depth dependency of thermo- and petrophysical rock parameters of the Upper Jurassic geothermal carbonate reservoirs of the Molasse Basin, Zeitschrift der Deutschen Gesellschaft für Geowissenschaften. 165, 469486.

Jensen, P.K., 1983. Calculations on the thermal conditions around a salt diapir, Geophysical Prospecting, 31, 481-489.

Jensen, P.K., 1990. Analysis of the temperature field around salt diapirs, Geothermics, 19, 273 283.

Kaiser, B.O., Cacace, M., Scheck-Wenderoth, M., 2013. 3D coupled fluid and heat transport simulations of the Northeast German Basin and their sensitivity to the spatial discretization: different sensitivities for different mechanisms of heat transport, Environmental Earth Sciences. 1-17.

Kaiser, B.O., Cacace, M., Scheck-Wenderoth, M., Lewerenz, B., 2011. Characterization of main heat transport processes in the Northeast German Basin: Constraints from 3-D numerical models, Geochem. Geophys. Geosyst. 12, Q07011.

Kaufhold, H., Hable, R., Liebsch-Dörschner, T., Thomsen, C., Taugs, R., 2011. Verbreitung und Eigenschaften mesozoischer Sandsteine sowie überlagernder Barrieregesteine in Schleswig-Holstein und Hamburg - Basisinformationen zur energiewirtschaftlichen Nutzung des tieferen Untergrundes, Schriftenreihe der Deutschen Gesellschaft für Geowissenschaften, 74, 38-60.

Kirsch, R., Balling, N., Fuchs, S., Hese, F., Hjuler, M., Kristensen, L., Mathiesen, A., Nielsen, C.M., Nielsen, L.H., Offermann, P., Poulsen, N.E., Rabbel, W., 2015. GeoPower - Varme fra undergrunden til Sønderjylland - Schleswig [Erdwärme für die Region Südjütland Schleswig], In: Kirsch, R. (Ed.) LLUR SH - Geologie und Boden, Landesamt für Landwirtschaft, Umwelt und ländliche Räume des Landes Schleswig-Holstein (LLUR), Kiel, Germany, pp. 70.

Kühne, K., 2006. Das Fachinformationssystem Geophysik und seine Nutzung über das Internet, In: Merkel, B., Schäben, H., Wolkersdorer, C., Hasche-Berger, A. (Eds.) 57. Berg- und Hüttenmännischer Tag "GIS - Geowissenschaftliche Anwendungen und Entwicklungen", Freiberg, pp. 227-231.

Magri, F., Bayer, U., Jahnke, C., Clausnitzer, V., Diersch, H.J., Fuhrman, J., Möller, P., Pekdeger, A., Tesmer, M., Voigt, H.J., 2005. Fluid-dynamics driving saline water in the North East German Basin, International Journal of Earth Sciences. 94, 1056-1069. 
Magri, F., Bayer, U., Tesmer, M., Möller, P., Pekdeger, A., 2008. Salinization problems in the NEGB: results from thermohaline simulations, International Journal of Earth Sciences, 97, 1075-1085.

Marotta, A.M., Bayer, U., Thybo, H., 2000. The legacy of the NE German Basin - reactivation by compressional buckling, Terra Nova, 12, 132-140.

Michelsen, O., Clausen, O.R., 2002. Detailed stratigraphic subdivision and regional correlation of the southern Danish Triassic succession, Marine and Petroleum Geology, 19, 563-587.

Maystrenko, Y., Bayer, U., Scheck-Wenderoth, M., 2005a. The Glueckstadt Graben, a sedimentary record between the North and Baltic Sea in north Central Europe, Tectonophysics, 397, 113-126.

Maystrenko, Y., Bayer, U., Scheck-Wenderoth, M., 2005b. Structure and evolution of the Glueckstadt Graben due to salt movements, International Journal of Earth Sciences, 94, 799814.

Maystrenko, Y.P., Bayer, U., Scheck-Wenderoth, M., 2006. 3D reconstruction of salt movements within the deepest post-Permian structure of the Central European Basin System - The Glueckstadt Graben, Geologie en Mijnbouw, 85, 181-196.

Maystrenko, Y.P., Scheck-Wenderoth, M., 2013. 3D lithosphere-scale density model of the Central European Basin System and adjacent areas, Tectonophysics. 601, 53-77.

Mottaghy, D., Pechnig, R., Vogt, C., 2011. The geothermal project Den Haag: 3D numerical models for temperature prediction and reservoir simulation, Geothermics. 40, 199-210.

Nielsen, L.H., 2003. Late Triassic - Jurassic development of the Danish Basin and the Fennoscandian Border Zone, southern Scandinavia. Geological Survey of Denmark and Greenland Bulletin, 1, 459-526.

Noack, V., Cherubini, Y., Scheck-Wenderoth, M., Lewerenz, B., Höding, T., Simon, A., Moeck, I., 2010. Assessment of the present-day thermal field (NE German Basin)-Inferences from 3D modelling, Chem Erde-Geochem. 70, 47-62.

Noack, V., Scheck-Wenderoth, M., Cacace, M., 2012. Sensitivity of 3D thermal models to the choice of boundary conditions and thermal properties: a case study for the area of Brandenburg (NE German Basin), Research Journal of Environmental and Earth Sciences. 67, 1695-1711.

Norden, B., Förster, A., 2006. Thermal conductivity and radiogenic heat production of sedimentary and magmatic rocks in the Northeast German Basin, AAPG Bulletin. 90, 939962.

Norden, B., Förster, A., Balling, N., 2008. Heat flow and lithospheric thermal regime in the Northeast German Basin, Tectonophysics. 460, 215-229.

Norden, B., Förster, A., Behrends, K., Krause, K., Stecken, L., Meyer, R., 2012. Geological 3D model of the larger Altensalzwedel area, Germany, for temperature prognosis and reservoir simulation, Environmental Earth Sciences. 67, 551-526.

Ollinger, D., Baujard, C., Kohl, T., Moeck, I., 2010. Distribution of thermal conductivities in the Groß Schönebeck (Germany) test site based on 3D inversion of deep borehole data, Geothermics. 39, 46-58.

Ondrak, R., Wenderoth, F., Scheck, M., Bayer, U., 1998. Integrated geothermal modeling on different scales in the Northeast German Basin, Geologische Rundschau, 87 (1998) 32-42

Ondrak, R., Klesper, C., Förster, A., Scheck, M., 1999. Das 3D Temperaturfeld des Nordostdeutschen Beckens - Vergleiche zwischen Bohrlochmessungen und einem 3-D Modell des konduktiven Wärmetransports. in: Terra Nostra - Rundgespräch zum DFGBündelantrag Begleitprojekte zu DEKORP NE-Deutschland pp. 33-37. 
Orilski, J., Schellschmidt, R., Wonik, T., 2010. Temperaturverlauf und Wärmeleitfähigkeit im Untergrund der Bohrung Groß Buchholz GT1 in Hannover, in: Geothermiekongress 2010, Karlsruhe, pp. 10.

Poulsen, S.E., Balling, N., Nielsen, S.B., , 2013. Analysis of bottom hole temperatures on- and nearshore Denmark, Research report, Department of Geoscience, Aarhus University, Denmark, 23 pp.

Powell, W.G., Chapman, D.S., Balling, N., Beck, A.E., 1988. Continental heat-flow density. in: R. Haenel, L. Rybach, L. Stegena (Eds.) Handbook Of Terrestrial Heat-Flow Density Determination, Kluwer Academic Publishers, Dodrecht, pp. 167-222.

Rodon, S., Littke, R., 2005. Thermal maturity in the Central European Basin system (Schleswig-Holstein area): results of 1D basin modelling and new maturity maps, International Journal of Earth Sciences, 94 (2005) 815-833.

Rybach, L., 1986. Amount and significance of radioactive heat sources in sediments. In: Burrus, J. (Ed.) Thermal Modelling in Sedimentary Basins: 1st IFP Exploration Research Conference Carcans, Editions Technip, Carcans, 311-322.

Scheck, M., 1997. Dreidimensionale Strukturmodellierung des Nordostdeutschen Beckens unter Einbeziehung von Krustenmodellen, In: Fachbereich Geowissenschaften, Freie Universität Berlin, Potsdam, Germany, pp. 126.

Scheck-Wenderoth, M., Cacace, M., Maystrenko, Y.P., Cherubini, Y., Noack, V., Kaiser, B.O., Sippel, J., Björn, L., 2014. Models of heat transport in the Central European Basin System: Effective mechanisms at different scales, Marine and Petroleum Geology, 55, 315-331.

Schulz, R., Werner, K.-H., 1987. Einfache Korrekturverfahren für Temperaturmessungen, In: Niedersächsisches Landesamt für Bodenforschung, Hannover, pp. 25.

Schütz, F., Fuchs, S., Förster, A., 2012a. Thermal conductivity of sedimentary rocks: the significance of facies-related trends. Geothermiekongress 2012 Karlsruhe, Germany.

Schütz, F., Norden, B., Förster, A., Desire Group, 2012b. Thermal properties of sediments in southern Israel: a comprehensive data set for heat flow and geothermal energy studies, Basin Research, 24, 357-376.

Seipold, U., 1990. Pressure and temperature dependence of thermal transport properties of granites, High Temp-High Press, 22, 541-548.

Sippel, J., Fuchs, S., Cacace, M., Braatz, A., Kastner, O., Huenges, E., Scheck-Wenderoth, M., 2013. Deep 3D thermal modelling for the city of Berlin (Germany), Environmental Earth Sciences, 70, 3545-3566.

Somerton, W. H. (1992). Thermal Properties and Temperature-Related Behavior of Rock/Fluid Systems. Amsterdam, Elsevier Science Publishers B.V., 257 pp.

Somerton W. H., Thermal Properties and Temperature-Related Behavior of Rock/Fluid Systems, 1992, Elsevier Science Publishers B.V., 257 pp.

Sorgenfrei, T., Buch, A., 1964. Deep Tests in Denmark. Geological Survey of Denmark, Copenhagen.

Thybo, H., 1997. Geophysical characteristics of the Tornquist Fan area, northwest TransEuropean Suture Zone: indication of late Carboniferous to early Permian dextral transtension, Geological Magazine, 134, 597-606.

Thybo, H., 2001. Crustal structure along the EGT profile across the Tornquist Fan interpreted from seismic, gravity and magnetic data, Tectonophysics, 334, 155-190.

Vogt, C., Mottaghy, D., Wolf, A., Rath, V., Pechnig, R., Clauser, C., 2010. Reducing temperature uncertainties by stochastic geothermal reservoir modelling, Geophysical Journal International. 181, 321-333. 
Vosteen, H.D., Rath, V., Schmidt-Mumm, A., Clauser, C., 2004. The thermal regime of the Northeastern-German Basin from 2-D inversion, Tectonophysics. 386, 81-95.

Vosteen, H.D., Schellschmidt, R., 2003. Influence of temperature on thermal conductivity, thermal capacity and thermal diffusivity for different types of rock, Physics and Chemistry of the Earth, 28, 499-509.

Ziegler, P.A., 1990. Geological Atlas of Western and Central Europe. in: P.A. Ziegler (Ed.), The Hague (Shell).

Ziegler, P.A., 1992. European Cenozoic rift system, Tectonophysics, 208, 91-111.

Zoth, G., Haenel, R., 1988. Appendix, in: R. Haenel, L. Rybach, L. Stegena (Eds.) Handbook of terrestrial heat-flow density determination, Kluwer Academic Publishers, Dordrecht, 449-468. 